\title{
Histobiometrical Study of the Ocular Muscles of Japanese Fetuses.
}

\author{
V. Size of Muscle Fibres.
}

By.

\begin{abstract}
Akira Hayashi.
From the Department of Anatomy, Keio University, Tokyo.

With to Text-figures.
\end{abstract}

Contents.

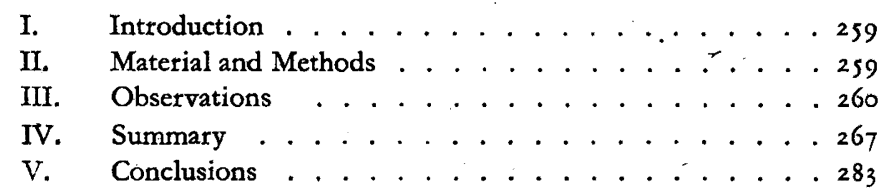

\section{Introduction.}

The size of muscle fibres in the human ocular muscles has already been studied by several authors as J. Halban (1894), G. Schwalbe and R. Mayeda (1899), P. Schiefferdecker (I904, I927), H. Voss (1935), Y. Kohashi (1937) and T. Kato (1938). But these authors studied only one or a few ocular muscles or ocular muscles of one or a few individuals and nobody has hitherto measured the size of the muscle fibres in seven ocular muscles of maný individuals in a certain period of age. In the present investigation, I have traced in detail the size of muscle fibres in the ocular muscles on both sides of Japanese fetuses in the 7 th-roth fetal month. The data obtained are presented here as the fifth report of the histobiometrical study of the ocular muscles.

\section{Material and Methods.}

In this study the material used was entirely the same as in the first report ${ }^{1)}$, comprising of total to-male and female-fetuses. The details are recorded

x) Histobiometrical Study of the Ocular Muscles of Japanese Fetuses. I. Number of Muscle Fibres. Okajimas Fol. anat. jap. Bd. 20. 194I. 
in Table I. All the cadavers were injected over the whole body and preserved in $10 \%$ formol solution.

The methods were also the same as those in the first report. The total ocular muscles dissected out of fetuses, dehydrated and embedded in celloidin. The preparation of the transverse sections was made in the midst of the belly of the ocular muscles at ro-rs $\mu$ in thickness. The sections, in which the whole muscle fibres transversely appeared, were stained with hematoxylin and eosin.

The muscle fibres in such transverse sections were projected at an enlargement of 600 upon a piece of paper and the area of cross-sections of 100 muscle fibres was measured. The average value of the true size of the roo fibres was calculated from the result of this measurement.

Table I. Material.

\begin{tabular}{|c|c|c|c|c|c|}
\hline Case & $\begin{array}{c}\text { Embryo- } \\
\text { number }\end{array}$ & Sex & Age & Stature & Body-weight \\
\hline I & 833 & $\delta$ & $7 \mathrm{~m}$ & $38.0 \mathrm{~cm}$ & $1000 \mathrm{gr}$ \\
2 & 1044 & 8 & 7 & 33.5 & 780 \\
3 & 969 & $\delta$ & 8 & 42.0 & 1440 \\
4 & 1109 & $f$ & 8 & 43.0 & 1665 \\
5 & 749 & $\delta$ & 9 & 46.5 & 2130 \\
6 & 552 & 8 & 9 & 46.0 & 2120 \\
7 & 1209 & $\delta$ & 10 & - & 3150 \\
8 & 966 & $\delta$ & 10 & 53.0 & 3310 \\
9 & 774 & 8 & 10 & 51.0 & 2600 \\
10 & 1193 & 8 & 10 & 52.0 & 2755 \\
\hline
\end{tabular}

\section{Observations.}

In the most ocular muscles, as described by Voss (1935) and $\mathrm{Kato}$ (1938), I could also divide the muscle fibres into two groups, i.e., axial thick and peripheral fine fibres. So I have carried out the measurement of the size of the fibres in the two-superficial and profound-parts. The data obtained is demonstrated in the following tables (Table 2-2 I). 
Table 2. Size of the axial thick fibres in the ocular muscles and comparison between the corresponding muscles on both sides in case $\mathbf{r}$.

\begin{tabular}{|c|c|c|c|c|c|c|}
\hline \multirow[b]{2}{*}{ 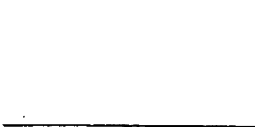 } & \multicolumn{3}{|c|}{ Size of the muscle fibres } & \multicolumn{3}{|c|}{ Percentage } \\
\hline & $\mathbf{R}$ & $\mathbf{L}$ & $\frac{\mathrm{R}+\mathrm{L}}{2}$ & $\frac{R}{R+L} \times 100$ & $\frac{\mathrm{L}}{\mathrm{R}+\mathrm{L}} \times 100$ & $\frac{\mathrm{R} \sim \mathrm{L}}{\mathrm{R}+\mathrm{L}} \times 100$ \\
\hline $\begin{array}{l}\text { Rectus superior } \\
\text { Rectus medialis } \\
\text { Rectus lateralis } \\
\text { Rectus inferior } \\
\text { Obliquus superior } \\
\text { Obliquus inferior } \\
\text { Levator palp. sup. }\end{array}$ & $\begin{array}{l}\text { sq. } \mu \\
142.1 \\
152.3 \\
184.8 \\
x 52.0 \\
135.2 \\
117.9 \\
172.9\end{array}$ & $\begin{array}{l}\text { sq. } \mu \\
200.1 \\
102.0 \\
110.9 \\
108.2 \\
181.3 \\
190.9 \\
140.7\end{array}$ & $\begin{array}{l}\text { sq. } \mu \\
\text { I } 7 \text { r.1 } \\
127.2 \\
147.9 \\
130.1 \\
158.3 \\
154.4 \\
156.8\end{array}$ & $\begin{array}{l}41.53 \% \\
59.89 \\
62.50 \\
58.42 \\
42.72 \\
38.18 \\
55.13\end{array}$ & $\begin{array}{l}58.47 \% \\
40.11 \\
37.50 \\
41.58 \\
57.28 \\
6 x .82 \\
44.87\end{array}$ & $\begin{array}{l}16.94 \% \\
19.78 \\
25.00 \\
16.84 \\
14.56 \\
23.64 \\
10.26\end{array}$ \\
\hline Average & 151.0 & 147.7 & I 49.4 & 51.20 & 48.80 & 19.15 \\
\hline Max.--Min. & 1.57 & 1.96 & 1.35 & - & - & 一 \\
\hline
\end{tabular}

In the Table 2-2I

$\mathrm{R}=$ Size of fibres in the right muscles, $\mathrm{L}=$ Size of fibres in the left muscles.

Table 3. Size of the peripheral fine fibres in the ocular muscles and comparison between the corresponding muscles on both sides in case $\mathrm{I}$.

\begin{tabular}{|c|c|c|c|c|c|c|}
\hline & \multicolumn{3}{|c|}{ Size of the muscle fibres } & \multicolumn{3}{|c|}{ Percentage } \\
\hline$=$ & $\mathbf{R}$ & $\mathbf{L}$ & $\frac{R+L}{2}$ & $\frac{\mathrm{R}}{\mathrm{R}+\mathrm{L}} \times 100$ & $\frac{\mathrm{L}}{\mathrm{R}+\mathrm{L}} \times 100$ & $\frac{\mathrm{R} \sim \mathrm{L}}{\mathrm{R}+\mathrm{L}} \times 100$ \\
\hline $\begin{array}{l}\text { Rectus superior } \\
\text { Rectus medialis } \\
\text { Rectus lateralis } \\
\text { Rectus inferior } \\
\text { Obliquus superior } \\
\text { Obliquus inferior } \\
\text { Levator palp. sup. }\end{array}$ & $\begin{array}{l}\text { sq. } \mu \\
71.5 \\
53.7 \\
47.1 \\
40.0 \\
42.8 \\
41.4 \\
59.3\end{array}$ & $\begin{array}{l}\text { sq. } \mu \\
66.6 \\
62.2 \\
34.7 \\
51.2 \\
73.6 \\
60.6 \\
44.8\end{array}$ & $\begin{array}{l}\text { sq.e } \\
69.1 \\
58.0 \\
40.9 \\
45.6 \\
58.2 \\
51.0 \\
52.1\end{array}$ & $\begin{array}{l}.51 .77 \% \\
46.33 \\
57.58 \\
43.86 \\
36.77 \\
40.59 \\
56.96\end{array}$ & $\begin{array}{l}48.23 \% \\
53.67 \\
42.42 \\
56.14 \\
63.23 \\
59.41 \\
43.04\end{array}$ & $\begin{array}{l}3.54 \% \\
7.34 \\
15.16 \\
12.28 \\
26.46 \\
18.82 \\
13.92\end{array}$ \\
\hline Average & 50.8 & 56.2 & 53.6 & 47.69 & 52.31 & 13.93 \\
\hline Max. $\div$ Min & I.79 & 2.12 & I. 42 & 一 & 一 & - \\
\hline
\end{tabular}

Table 4. Size of the axial thick fibres in the ocular muscles and comparison between the corresponding muscles on both sides in case 2 .

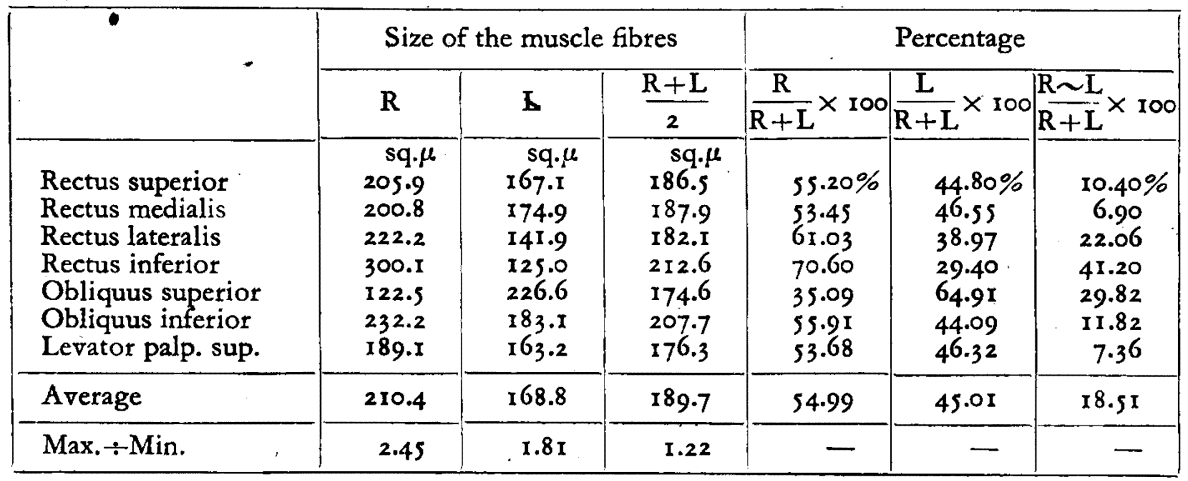


Table s. Size of the peripheral fine fibres in the ocular muscles and comparison between the corresponding muscles on both sides in case 2 .

\begin{tabular}{|l|c|c|c|c|c|c|}
\hline & \multicolumn{3}{|c|}{ Size of the muscle fibres } & \multicolumn{3}{|c|}{ Percentage } \\
\cline { 2 - 7 } & $\mathrm{R}$ & $\mathrm{L}$ & $\frac{\mathrm{R}+\mathrm{L}}{2}$ & $\frac{\mathrm{R}}{\mathrm{R}+\mathrm{L}} \times 100$ & $\frac{\mathrm{L}}{\mathrm{R}+\mathrm{L}} \times 100$ & $\frac{\mathrm{R} \sim \mathrm{L}}{\mathrm{R}+\mathrm{L}} \times 100$ \\
\hline & $\mathrm{sq. \mu}$ & sq. $\mu$ & $\mathrm{sq} . \mu$ & & & \\
Rectus superior & 83.4 & 110.9 & 97.2 & $42.92 \%$ & $57.08 \%$ & $14.16 \%$ \\
Rectus medialis & 86.8 & 90.0 & 88.4 & 49.10 & 50.90 & 1.80 \\
Rectus lateralis & 100.6 & 92.7 & 96.7 & 52.04 & 47.96 & 4.08 \\
Rectus inferior & 87.4 & 100.0 & 93.7 & 46.64 & 53.36 & 6.72 \\
Obliquus superior & 90.4 & 106.7 & 98.6 & 45.87 & 54.13 & 8.26 \\
Obliquus inferior & 88.9 & 109.0 & 99.0 & 44.92 & 55.08 & 10.16 \\
Levator palp. sup. & $83.3-$ & 101.6 & 92.5 & 45.05 & 54.95 & 9.90 \\
\hline Average & 88.7 & 101.6 & 95.2 & 46.65 & 53.35 & 7.87 \\
\hline Max.+Min. & 1.21 & 1.23 & 1.12 & - & - & - \\
\hline
\end{tabular}

Table 6. Size of the axial thick fibres in the ocular muscles and comparison between the corresponding muscles on both sides in case 3 .

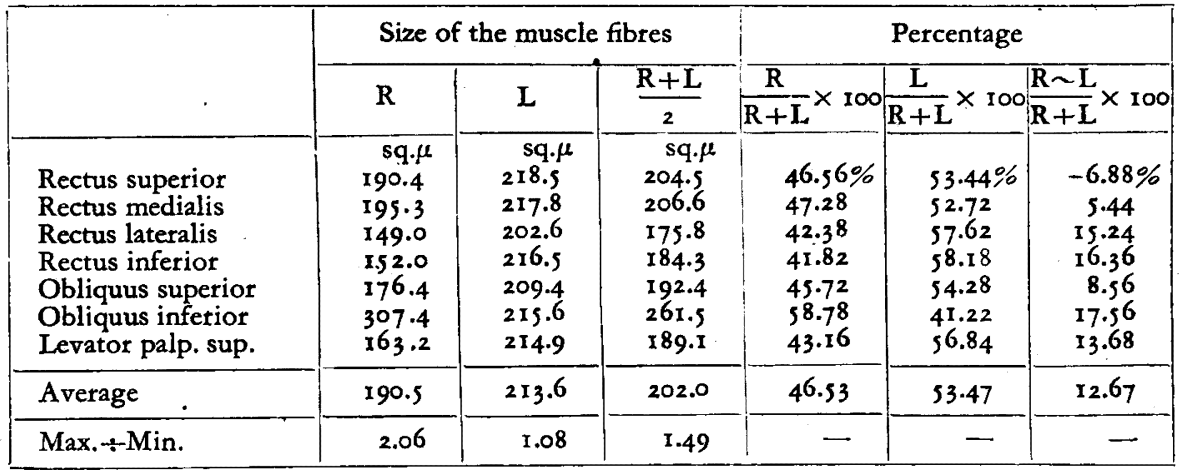

Table 7. Size of the peripheral fine fibres in the ocular muscles and comparison between the corresponding muscles on both sides in case 3 .

\begin{tabular}{|c|c|c|c|c|c|c|}
\hline & \multicolumn{3}{|c|}{ Size of the muscle fibres } & \multicolumn{3}{|c|}{ Percentage } \\
\hline$\therefore$ & . $\mathrm{R}$ & $\mathbf{L}$ & $\frac{R+L}{2}$ & $\frac{\mathrm{R}}{\mathrm{R}+\mathrm{L}} \times 100$ & $\frac{L}{R+L} \times 100$ & $\frac{\mathrm{R} \sim \mathrm{L}}{\mathrm{R}+\mathrm{L}} \times 100$ \\
\hline $\begin{array}{l}\text { Rectus superior } \\
\text { Rectus medialis } \\
\text { Rectus lateralis } \\
\text { Rectus inferior } \\
\text { Obliquus superior } \\
\text { Obliquus inferior } \\
\text { Levator palp. sup. }\end{array}$ & $\begin{array}{l}\text { sq. } \mu \\
65.5 \\
59.4 \\
61.5 \\
58.6 \\
57.8 \\
65.8 \\
64.3 \\
\end{array}$ & $\begin{array}{l}\text { sq. } \mu \\
72.1 \\
62.1 \\
69.4 \\
64.0 \\
68.5 \\
69.1 \\
72.1 \\
\end{array}$ & $\begin{array}{l}\text { sq. } \mu \\
68.8 \\
60.8 \\
65.5 \\
61.3 \\
63.2 \\
67.5 \\
68.2 \\
\end{array}$ & $\begin{array}{l}47.60 \% \\
48.89 \\
45.98 \\
47.80 \\
45 \cdot 76 \\
48.78 \\
47.14\end{array}$ & $\begin{array}{l}52.40 \% \\
51.11 \\
54.02 \\
52.20 \\
54.28 \\
51.26 \\
52.86 \\
\end{array}$ & $\begin{array}{l}4.80 \% \\
2.22 \\
8.04 \\
4.40 \\
8.48 \\
2.48 \\
5.7^{2} \\
\end{array}$ \\
\hline Average & 61.8 & 68.2 & 65.0 & $47 \cdot 4 I$ & 52.59 & 10.62 \\
\hline Max. $\div$ Min. & $x .07$ & Ix 6 & I.I 3 & - & - & 一 \\
\hline
\end{tabular}


Table 8. Size of the axial thick fibres in the ocular muscles and comparison between the corresponding muscles on both sides in case 4 .

\begin{tabular}{|c|c|c|c|c|c|c|}
\hline & \multicolumn{3}{|c|}{ Size of the muscle fibres } & \multicolumn{3}{|c|}{ Percentage } \\
\hline & $\mathbf{R}$ & $\mathbf{L}$ & $\frac{\mathrm{R}+\mathrm{L}}{2}$ & $\frac{\mathrm{R}}{\mathrm{R}+\mathrm{L}} \times 100$ & $\frac{\mathrm{L}}{\mathrm{R}+\mathrm{L}} \times 100$ & $\frac{\mathrm{R} \sim \mathrm{L}}{\mathrm{R}+\mathrm{L}} \times 100$ \\
\hline $\begin{array}{l}\text { Rectus superior } \\
\text { Rectus medialis } \\
\text { Rectus lateralis } \\
\text { Rectus inferior } \\
\text { Obliquus superior } \\
\text { Obliquus inferior } \\
\text { Levator palp. sup. }\end{array}$ & $\begin{array}{l}\text { sq. } \mu \\
296.7 \\
225.8 \\
244.9 \\
173.1 \\
145.8 \\
184.3 \\
183.4\end{array}$ & $\begin{array}{l}\text { sq. } \mu \\
368.7 \\
272.4 \\
280.3 \\
211.0 \\
186.0 \\
199.0 \\
216.5\end{array}$ & $\begin{array}{l}\text { sq. } \mu \\
332.7 \\
249.1 \\
262.6 \\
192.1 \\
165.9 \\
187.7 \\
199.8 \\
\end{array}$ & $\begin{array}{l}44.59 \% \\
45.32 \\
46.63 \\
45.07 \\
43.94 \\
49.11 \\
45.91 \\
\end{array}$ & $\begin{array}{l}55.41 \% \\
54.68 \\
53.37 \\
54.93 \\
56.06 \\
50.89 \\
54.09 \\
\end{array}$ & $\begin{array}{c}10.82 \% \\
9.36 \\
6.74 \\
9.86 \\
12.12 \\
1.78 \\
8.18 \\
\end{array}$ \\
\hline Average & 207.7 & 246.6 & 227.2 & 45.80 & 54.20 & $8.4 \mathrm{I}$ \\
\hline Max.-Min. & 2.03 & 1.98 & $0.2 \mathrm{I}$ & - & - & - \\
\hline
\end{tabular}

Table 9. Size of the peripheral fine fibres in the ocular muscles and comparison between the corresponding muscles on both sides in case 4 .

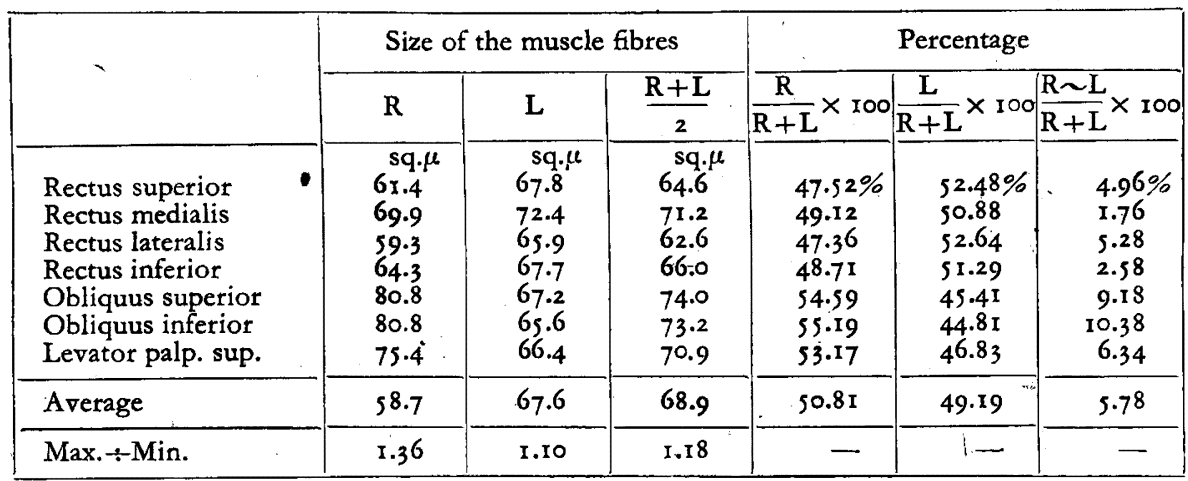

Table 10. Size of the axial thick fibres in the ocular muscles and comparison between the corresponding muscles on both sides in case 5 .

\begin{tabular}{|c|c|c|c|c|c|c|}
\hline & \multicolumn{3}{|c|}{ Size of the muscle fibres } & \multicolumn{3}{|c|}{ Percentage } \\
\hline , & $\mathbf{R}$ & $\mathbf{L}$ & $\frac{R+L}{2}$ & $\frac{\mathrm{R}}{\mathrm{R}+\mathrm{L}} \times 100$ & $\frac{-\mathrm{L}}{\mathrm{R}+\mathrm{L}} \times 100$ & $\frac{\mathrm{R} \sim \mathrm{L}}{\mathrm{R}+\mathrm{L}} \times 100$ \\
\hline $\begin{array}{l}\text { Rectus superior } \\
\text { Rectus medialis } \\
\text { Rectus lateralis } \\
\text { Rectus inferior } \\
\text { Obliquus superior } \\
\text { Obliquus inferior } \\
\text { Levator palp. sup. }\end{array}$ & $\begin{array}{l}\text { sq. } \mu \\
320.8 \\
302.1 \\
335.5 \\
366.0 \\
363.8 \\
401.6 \\
403.1\end{array}$ & $\begin{array}{l}\text { sq. } \mu \\
244.8 \\
309.6 \\
303.8 \\
297.5 \\
287.1 \\
289.6 \\
273.3\end{array}$ & $\begin{array}{l}\text { sq. } \mu \\
282.8 \\
305.9 \\
319.7 \\
3 \times 6.8 \\
325.5 \\
345.6 \\
288.2\end{array}$ & $\begin{array}{l}56.72 \% \\
49.39 \\
52.48 \\
55.16 \\
55.89 \\
58.10 \\
69.93\end{array}$ & $\begin{array}{l}43.28 \% \\
50.61 \\
47.52 \\
44.84 \\
44.11 \\
41.90 \\
30.07\end{array}$ & $\begin{array}{r}13.44 \% \\
1.22 \\
4.96 \\
10.32 \\
11.78 \\
16.20 \\
39.86\end{array}$ \\
\hline Average & 356.1 & 272.2 & 312.1 & 56.81 & 43.19 & 13.97 \\
\hline Max. $\div$ Min. & I.33 & 1.79 & 1.22 & - & - & ' - \\
\hline
\end{tabular}


Table II. Size of the peripheral fine fibres in the ocular muscles and comparison between the corresponding muscles on both sides in case 5 .

\begin{tabular}{|c|c|c|c|c|c|c|}
\hline \multirow[t]{2}{*}{ (2) } & \multicolumn{3}{|c|}{ Size of the muscle fibres } & \multicolumn{3}{|c|}{ Percentage } \\
\hline & $\mathbf{R}$ & $\mathbf{L}$ & $\frac{\mathrm{R}+\mathrm{L}}{2}$ & $\frac{R}{R+L} \times 100$ & $\frac{L}{R+L} \times 100$ & $\frac{\mathbf{R} \sim \mathbf{L}}{\mathbf{R}+\mathbf{L}} \times 100$ \\
\hline Rectus superior & $\begin{array}{l}\text { sq. } \mu \\
\text { ro3.4 }\end{array}$ & $\begin{array}{l}\text { sq. } \mu \\
99.1\end{array}$ & $\begin{array}{c}\text { sq. } \mu \\
\text { ror.3 }\end{array}$ & $51.06 \%$ & $48.94 \%$ & $2.12 \%$ \\
\hline $\begin{array}{l}\text { Rectus medialis } \\
\text { Rectus lateralis }\end{array}$ & $\begin{array}{l}90.0 \\
96.4\end{array}$ & $\begin{array}{l}100.1 \\
106.8\end{array}$ & $\begin{array}{r}95.1 \\
101.6\end{array}$ & $\begin{array}{l}47 \cdot 34 \\
47 \cdot 44\end{array}$ & $\begin{array}{l}52.66 \\
52.56\end{array}$ & $\begin{array}{l}5.32 \\
5.12\end{array}$ \\
\hline Rectus inferior & 95.9 & 107.5 & $\begin{array}{l}101.0 \\
101.7\end{array}$ & $\begin{array}{l}47 \cdot 44 \\
47 \cdot 15\end{array}$ & $\begin{array}{l}52.50 \\
52.85\end{array}$ & 5.120 \\
\hline Obliquus superior & I01.7 & 103.4 & 102.6 & 49.59 & 50.41 & 0.82 \\
\hline Obliquus inferior & 94.4 & $95 \cdot 7$ & $95 \cdot 1$ & 49.66 & 50.34 & 0.68 \\
\hline Levatot palp. sup. & $99.0^{\circ}$ & 99.2 & 99.1 & 49.95 & 50.05 & 0.10 \\
\hline Average & $97 \cdot 3$ & $7 \times 1.8$ & 99.5 & 48.88 & 51.12 & 2.84 \\
\hline Max. $\div$ Min. & 1.15 & 1.12 & 1.08 & 1.08 & - & - \\
\hline
\end{tabular}

Table I2. Size of the axial thick fibres in the ocular muscles and comparison between the corresponding muscles on both sides in case 6.

\begin{tabular}{|c|c|c|c|c|c|c|}
\hline & \multicolumn{3}{|c|}{ Size of the muscle fibres } & \multicolumn{3}{|c|}{ Percentage } \\
\hline & $\mathbf{R}$ & $\mathbf{L}$ & $\frac{R+L}{2}$ & $\frac{\mathrm{R}}{\mathrm{R}+\mathrm{L}} \times 100$ & $\frac{\mathrm{L}}{\mathrm{R}+\mathrm{L}} \times 100$ & $\frac{\mathrm{R} \sim \mathrm{L}}{\mathrm{R}+\mathrm{L}} \times 100$ \\
\hline Rectus superior & $\begin{array}{l}\text { sq. } \mu \\
14 \mathrm{I} . \mathrm{I}\end{array}$ & $\begin{array}{l}\text { sq. } \mu \\
\text { I } 3.1\end{array}$ & $\begin{array}{r}\text { sq. } \mu \\
\text { I } 27.1\end{array}$ & $55.51 \%$ & $44.49 \%$ & I $1.02 \%$ \\
\hline Rectus medialis & II 1.1 & 150.3 & 130.7 & 42.50 & $\begin{array}{l}44.45 \% \\
57 \cdot 50\end{array}$ & 15.00 \\
\hline Rectus lateralis & 142.6 & 187.5 & 165.1 & 43.20 & 56.80 & 13.60 \\
\hline Rectus inferior & 104.9 & 188.1 & 146.5 & 35.80 & 64.20 & 28.40 \\
\hline Obliquus superior & 122.7 & 196.2 & 159.5 & 38.48 & $6 \mathrm{I} \cdot 52$ & 23.04 \\
\hline Obliquus inferior & 106.3 & 202.6 & 154.5 & $34.4 \mathrm{I}$ & 65.59 & $3 I .18$ \\
\hline Levator palp. sup. & 109.4 & 167.2 & $\times 78.3$ & - 30.68 & 69.32 & 38.64 \\
\hline Average & II9.7 & 172.1 & 151.7 & 40.08 & 59.92 & 22.98 \\
\hline Max. - Min. & 1.36 & $\mathrm{r} .79$ & 1.36 & - & - & 一 \\
\hline
\end{tabular}

Table 13. Size of the peripheral fine fibres in the ocular muscles and comparison between the corresponding muscles on both sides in case 6 .

\begin{tabular}{|c|c|c|c|c|c|c|}
\hline & \multicolumn{3}{|c|}{ Size of the muscle fibres } & \multicolumn{3}{|c|}{ Percentage, } \\
\hline , & $\mathbf{R}$ & L & $\frac{R+L}{2}$ & $\frac{\mathrm{R}}{\mathrm{R}+\mathrm{L}} \times 100$ & $\frac{\mathrm{L}}{\mathrm{R}+\mathrm{L}} \times 100$ & $\frac{\mathrm{R} \sim \mathrm{L}}{\mathrm{R}+\mathrm{L}} \times \mathrm{ro0}$ \\
\hline $\begin{array}{l}\text { Rectus superior } \\
\text { Rectus medialis } \\
\text { Rectus lateralis } \\
\text { Rectus inferior } \\
\text { Obliquus superior } \\
\text { Obliquus inferior } \\
\text { Levator palp. sup. }\end{array}$ & $\begin{array}{l}\text { sq. } \mu \\
73.6 \\
71.3 \\
79.1 \\
77.4 \\
73.6 \\
73.3 \\
76.4\end{array}$ & $\begin{array}{c}\text { sq. } \mu \\
81.8 \\
78.2 \\
118.9 \\
95.7 \\
95.0 \\
94.0 \\
104.4\end{array}$ & $\begin{array}{c}\text { sq. } \mu \\
77.7 \\
74.8 \\
99.0 \\
86.9 \\
84.3 \\
83.7 \\
90.4\end{array}$ & $\begin{array}{l}47 \cdot 36 \% \\
47.69 \\
39.95 \\
44.56 \\
43.65 \\
43.81 \\
42.26\end{array}$ & $\begin{array}{l}52.64 \% \\
52.31 \\
60.05 \\
55.44 \\
56.35 \\
56.19 \\
57.74\end{array}$ & $\begin{array}{l}5.28 \% \\
4.62 \\
20.10 \\
10.88 \\
12.70 \\
12.38 \\
15.48\end{array}$ \\
\hline Average & 75.0 & 95.4 & 85.3 & $44 \cdot 18$ & 55.82 & 11.63 \\
\hline $\operatorname{Max} . \div$ Min. & I.II & $x .52$ & 1.32 & - & - & $1-$ \\
\hline
\end{tabular}


Table 14. Size of the axial thick fibres in the ocular muscles and comparison between the corresponding muscles on both sides in case 7 .

\begin{tabular}{|c|c|c|c|c|c|c|}
\hline \multirow[t]{2}{*}{. } & \multicolumn{3}{|c|}{ Size of the muscle fibres } & \multicolumn{3}{|c|}{ Percentage } \\
\hline & $\mathrm{R}$ & $\mathbf{L}$ & $\frac{R+L}{2}$ & $\frac{R}{R+L} \times 100$ & $\frac{\mathrm{L}}{\mathrm{R}+\mathrm{L}} \times 100$ & $\frac{\mathrm{R} \sim \mathrm{L}}{\mathrm{R}+\mathrm{L}} \times 100$ \\
\hline Rectus superior & $\begin{array}{l}\text { sq. } \mu \\
121.3\end{array}$ & $\begin{array}{l}\text { sq. } \mu \\
117.5\end{array}$ & $\begin{array}{c}\text { sq. } \mu \\
179 \cdot 4\end{array}$ & $50.80 \%$ & $49.20 \%$ & $1.60 \%$ \\
\hline Rectus medialis & II 6.9 & 97.8 & 107.4 & $54 \cdot 45$ & 45.55 & $8.90^{\circ}$ \\
\hline Rectus lateralis & $141 \cdot 7$ & 100.8 & 121.3 & 58.43 & 41.57 & 16.86 \\
\hline Rectus inferior & 110.5 & 98.3 & $104 \cdot 4$ & 52.92 & 47.08 & 5.84 \\
\hline Obliquus superior & 126.4 & 100.6 & 113.5 & 55.68 & $44 \cdot 32$ & 11.36 \\
\hline Obliquus inferior & 108.5 & $99 \cdot 5$ & 104.0 & 52.16 & 47.84 & 4.32 \\
\hline Levator palp. sup. & 128.6 & 102.7 & II 5.7 & 55.60 & $44 \cdot 40$ & 11.20 \\
\hline Average & 122.0 & 102.5 & I 21.0 & 54.29 & $45 \cdot 71$ & 8.58 \\
\hline Max.-Min. & 1.31 & 1.20 & 1.17 & - & 一 & - \\
\hline
\end{tabular}

Table 15. Size of the peripheral fine fibres in the ocular muscles and comparison between the corresponding muscles on both sides in case 7 .

\begin{tabular}{|c|c|c|c|c|c|c|}
\hline \multirow[b]{2}{*}{. } & \multicolumn{3}{|c|}{ Size of the muscle fibres } & \multicolumn{3}{|c|}{ Percentage } \\
\hline & $\mathbf{R}$ & L & $\frac{R+L}{2}$ & $\frac{R}{R+L} \times 100$ & $\frac{\mathrm{L}}{\mathrm{R}+\mathrm{L}} \times 100$ & $\frac{R \sim L}{R+L} \times 100$ \\
\hline Rectus superior & $\begin{array}{l}\text { sq. } \mu \\
\text { I07.5 }\end{array}$ & $\begin{array}{l}\text { sq. } \mu \\
s 3.0\end{array}$ & $\begin{array}{l}\text { sq. } \mu \\
80.3\end{array}$ & $66.98 \%$ & $33.02 \%$ & $33.96 \%$ \\
\hline Rectus medialis & $59 \cdot 2$ & $47 \cdot 3$ & 53.3 & 55.59 & $44 \cdot 41$ & II. 18 \\
\hline Rectus lateralis & 83.4 & 58.6 & 71.0 & 58.73 & 41.27 & 17.46 \\
\hline Rectus inferior & $75 \cdot 4$ & $49 \cdot 7$ & 62.6 & 60.27 & $39 \cdot 73$ & 20.54 \\
\hline Obliquus superior & 79.5 & $48 \cdot 9$ & $64 \cdot 2$ & 61.92 & 38.08 & 23.84 \\
\hline Obliquus inferior & 62.3 & 58.0 & 60.2 & $57 \cdot 79$ & 42.21 & 15.58 \\
\hline Levator palp. sup. & $77 \cdot 9$ & 56.0 & $67 \cdot 0$ & 58.18 & 41.82 & 16.36 \\
\hline Average & $77 \cdot 9$ & 53.1 & 65.5 & 59.92 & 40.08 & 19.85 \\
\hline Max. $\div$ Min. & $\mathrm{x} .82$ & 1.24 & $I .5 I$ & - & - & - \\
\hline
\end{tabular}

Table i6. Size of the axial thick fibres in the ocular muscles and comparison between the corresponding muscles on both sides in case 8 .

\begin{tabular}{|c|c|c|c|c|c|c|}
\hline \multirow[b]{2}{*}{ - } & \multicolumn{3}{|c|}{ Size of the muscle fibres } & \multicolumn{3}{|c|}{ Percentage } \\
\hline & $\mathbf{R}$ & L & $\frac{\mathrm{R}+\mathrm{L}}{2}$ & $\frac{\mathrm{R}}{\mathrm{R}+\mathrm{L}} \times 100$ & $\frac{\mathrm{L}}{\mathrm{R}+\mathrm{L}} \times 100$ & $\frac{\mathrm{R} \sim \mathrm{L}}{\mathrm{R}+\mathrm{L}} \times 100$ \\
\hline Rectus superior & $\begin{array}{l}\text { sq. } \mu \\
272.0\end{array}$ & $\begin{array}{l}\text { sq. } \mu \\
216.5\end{array}$ & $\begin{array}{l}\text { sq. } \mu \\
244.3\end{array}$ & $55.68 \%$ & $44.32 \%$ & $11.36 \%$ \\
\hline Rectus medialis & $314 \cdot 1$ & 285.0 & 299.7 & $52.4 \mathrm{I}$ & $=47.59$ & 4.82 \\
\hline Rectus lateralis & $414 \cdot 0$ & $429 \cdot I$ & 421.6 & $49 \cdot 10$ & 50.90 & 1.80 \\
\hline Rectus inferior & $39 x \cdot 3$ & 223.2 & 307.3 & 63.68 & 36.32 & $27 \cdot 36$ \\
\hline Obliquus superior & 375.1 & 282.1 & 328.6 & 57.08 & 42.92 & $14 \cdot 16$ \\
\hline Obliquus inferior & 382.7 & $275 \cdot 7$ & 263.4 & 58.13 & 41.87 & 16.26 \\
\hline Levator palp. sup. & $374 \cdot 4$ & 256.3 & $3 \times 5.4$ & $59 \cdot 36$ & 40.64 & 18.72 \\
\hline Average & 359.5 & $28 \mathrm{I} \cdot \mathrm{I}$ & 311.5 & 56.49 & $43 \cdot 5 \mathrm{I}$ & 13.50 \\
\hline Max.-Min. & 1.52 & $\mathrm{x} .98$ & 1.73 & $\div$ & 一 & 一 \\
\hline
\end{tabular}


'Table 17. Size of the peripheral fine fibres in the ocular muscles and comparison between the corresponding muscles on both sides in case 8 .

\begin{tabular}{|c|c|c|c|c|c|c|}
\hline \multirow{2}{*}{. } & \multicolumn{3}{|c|}{ Size of the muscle fibres } & \multicolumn{3}{|c|}{ Percentage } \\
\hline & $\mathbf{R}$ & $\mathbf{L}$ & $\frac{R+L}{2}$. & $\frac{R}{R+L} \times 100$ & $\frac{\mathrm{L}}{\mathrm{R}+\mathrm{L}} \times 100$ & $\frac{\mathrm{R} \sim \mathrm{L}}{\mathrm{R}+\mathrm{L}} \times 100$ \\
\hline $\begin{array}{l}\text { Rectus superior } \\
\text { Rectus medialis } \\
\text { Rectus lateralis } \\
\text { Rectus inferior } \\
\text { Obliquus superior } \\
\text { Obliquus inferior } \\
\text { Levator palp. sup. }\end{array}$ & $\begin{array}{l}\text { sq. } \mu \\
84.5 \\
75 \cdot 7 \\
70.8 \\
77.6 \\
75.0 \\
75.0 \\
74.1\end{array}$ & $\begin{array}{r}\text { sq. } \mu \\
104.4 \\
99.6 \\
116.0 \\
104.6 \\
96.0 \\
101.2 \\
90.2\end{array}$ & $\begin{array}{l}\text { sq. } \mu \\
94.5 \\
87.7 \\
93.4 \\
90.9 \\
85.5 \\
88.1 \\
82.2\end{array}$ & $\begin{array}{l}44 \cdot 73 \% \\
43 \cdot 18 \\
37 \cdot 90 \\
42.71 \\
43.86 \\
42.57 \\
45.10\end{array}$ & $\begin{array}{l}55.27 \% \\
56.82 \\
62.10 \\
57.29 \\
56.14 \\
57.43 \\
54.90\end{array}$ & $\begin{array}{l}10.54 \% \\
13.64 \\
24.20 \\
14.58 \\
12.28 \\
14.91 \\
9.80\end{array}$ \\
\hline Average & $7^{6.1}$ & 101.6 & 88.9 & 42.86 & $57 \cdot 14$ & 14.28 \\
\hline Max.-Min. & I.I 9 & 1.29 & 1.15 & - & - & - \\
\hline
\end{tabular}

Table 18. Size of the axial thick fibres in the ocular muscles and comparison between the corresponding muscles on both sides in case 9 .

\begin{tabular}{|c|c|c|c|c|c|c|}
\hline & \multicolumn{3}{|c|}{ Size of the muscle fibres } & \multicolumn{3}{|c|}{ Percentage } \\
\hline . & $\mathbf{R}$ & $\mathbf{L}$ & $\frac{R+L}{2}$. & $\frac{R}{R+L} \times 100$ & $\frac{\mathbf{L}}{\mathrm{R}+\mathrm{L}} \times 100$ & $\int \frac{\mathrm{R} \sim \mathrm{L}}{\mathrm{R}+\mathrm{L}} \times 100$ \\
\hline $\begin{array}{l}\text { Rectus superior } \\
\text { Rectus medialis } \\
\text { Rectus lateralis } \\
\text { Rectus inferior } \\
\text { Obliquus superior } \\
\text { Obliquus inferior } \\
\text { Levator palp. sup. }\end{array}$ & $\begin{array}{l}\text { sq. } \mu \\
492.8 \\
507.2 \\
490.0 \\
419.5 \\
449.6 \\
228.9 \\
470.7 \\
\end{array}$ & $\begin{array}{l}\text { sq. } \mu \\
357.6 \\
438.6 \\
411.8 \\
401.6 \\
384.7 \\
385.9 \\
397: 3\end{array}$ & $\begin{array}{l}\text { sq. } \mu \\
425.2 \\
472.9 \\
450.9 \\
410.6 \\
417.2 \\
307.4 \\
434.0 \\
\end{array}$ & $\begin{array}{l}57.95 \% \\
53.63 \\
54.34 \\
51.09 \\
53.89 \\
37.23 \\
54.23 \\
\end{array}$ & $\begin{array}{l}42.05 \% \\
46.37 \\
45.66 \\
48.91 \\
46.11 \\
62.77 \\
45.77\end{array}$ & $\begin{array}{c}15.90 \% \\
7.26 \\
8.68 \\
2.18 \\
7.78 \\
25.54 \\
8.46\end{array}$ \\
\hline Average & 437.1 & 397.8 & 417.9 & 51.77 & 48.23 & 10.83 \\
\hline Max. -Min. & 2.22 & 1.23 & 1.54 & - & - & - \\
\hline
\end{tabular}

Table 19. Size of the peripheral fine fibres in the ocular muscles and comparison between the corresponding muscles on both sides in case 9 .

\begin{tabular}{|c|c|c|c|c|c|c|}
\hline \multirow[b]{2}{*}{ - } & \multicolumn{3}{|c|}{ Size of the muscle fibres } & \multicolumn{3}{|c|}{ Percentage } \\
\hline & $\mathbf{R}$ & $\mathbf{L}$ & $\frac{R+L}{2}$ & $\frac{R}{R+L} \times 100$ & $\frac{\mathrm{L}}{\mathrm{R}+\mathrm{L}} \times 100$ & $\frac{\mathrm{R} \sim \mathrm{L}}{\mathrm{R}+\mathrm{L}} \times 100$ \\
\hline $\begin{array}{l}\text { Rectus superior } \\
\text { Rectus medialis } \\
\text { Rectus lateralis } \\
\text { Rectus inferior } \\
\text { Obliquus superior } \\
\text { Obliquus inferior } \\
\text { Levator palp. sup. }\end{array}$ & $\begin{array}{l}\text { sq. } \mu \\
97.3 \\
80.2 \\
97.7 \\
109.2 \\
107.6 \\
95.0 \\
\text { x } 10.5\end{array}$ & $\begin{array}{l}\text { sq. } \mu \\
\text { I } 99.2 \\
\text { I } 22.8 \\
\text { I } 8.6 \\
108.1 \\
107.5 \\
109.8 \\
105.3\end{array}$ & $\begin{array}{l}\text { sq. } \mu \\
148.3 \\
101.5 \\
108.2 \\
108.7 \\
107.6 \\
102.4 \\
107.9\end{array}$ & $\begin{array}{l}32.82 \% \\
39.51 \\
45.17 \\
50.25 \\
50.02 \\
46.39 \\
51.20\end{array}$ & $\begin{array}{l}67.18 \% \\
60.49 \\
54.83 \\
49.75 \\
49.98 \\
53.61 \\
48.80\end{array}$ & $\begin{array}{l}34.36 \% \\
20.98 \\
9.66 \\
0.50 \\
0.04 \\
7.22 \\
2.40\end{array}$ \\
\hline Average & 99.6 & 124.5 & I 22.1 & 45.05 & 54.95 & 10.74 \\
\hline Max. $\div$ Min & I. 38 & I.89 & 1.46 & - & 一 & - \\
\hline
\end{tabular}


Table 20. Size of the axial thick fibres in the ocular muscles and comparison between the corresponding muscles on both sides in case ro.

\begin{tabular}{|c|c|c|c|c|c|c|}
\hline & \multicolumn{3}{|c|}{ Size of the muscle fibres } & \multicolumn{3}{|c|}{ Percentage } \\
\hline & $\mathbf{R}$ & $\mathrm{L}$ & $\frac{\mathrm{R}+\mathrm{L}}{2}$ & $\frac{\mathrm{R}}{\mathrm{R}+\mathrm{L}} \times 100$ & $\frac{L}{R+L} \times 100$ & $\frac{\mathrm{R} \sim \mathrm{L}}{\mathrm{R}+\mathrm{L}}+\mathrm{r} 00$ \\
\hline $\begin{array}{l}\text { Rectus superior } \\
\text { Rectus medialis } \\
\text { Rectus lateralis } \\
\text { Rectus inferior } \\
\text { Obliquus superior } \\
\text { Obliquus infferior } \\
\text { Levator palp. sup. }\end{array}$ & $\begin{array}{l}\text { sq. } \mu \\
365.3 \\
328.0 \\
332.3 \\
357.9 \\
340.2 \\
358.0 \\
333.0\end{array}$ & $\begin{array}{l}\text { sq. } \mu \\
308.1 \\
286.6 \\
365.4 \\
325.5 \\
227 \cdot 3 \\
269 \cdot 3 \\
216.3\end{array}$ & $\begin{array}{l}\text { sq. } \mu \\
336.7 \\
307.3 \\
348.9 \\
34 \mathrm{re} \\
283.8 \\
313.7 \\
274.7\end{array}$ & $\begin{array}{l}54.25 \% \\
53.37 \\
47.63 \\
52.37 \\
59.95 \\
57.07 \\
60.62\end{array}$ & $\begin{array}{l}45.75 \% \\
46.63 \\
52.37 \\
47.63 \\
40.05 \\
42.93 \\
39.38\end{array}$ & $\begin{array}{l}8.50 \% \\
6.74 \\
4.74 \\
4.74 \\
19.90 \\
14.14 \\
21.24\end{array}$ \\
\hline Average & $345 \cdot I$ & 285.5 & 315.3 & .55 .04 & 44.96 & II.43 \\
\hline Max. $\div$ Min & I.II & 1.69 & I.27 & - & 一 & - \\
\hline
\end{tabular}

Table 21 . Size of the peripheral fine fibres in the ocular muscles and com-. parison between the corresponding muscles on both sides in case 10.

\begin{tabular}{|c|c|c|c|c|c|c|}
\hline & \multicolumn{3}{|c|}{ Size of the muscle fibres } & \multicolumn{3}{|c|}{ Percentage } \\
\hline & $\mathbf{R}$ & $\mathbf{L}$ & $\frac{R+L}{2}$ & $\frac{\mathrm{R}}{\mathrm{R}+\mathrm{L}} \times 100$ & $\frac{\mathrm{L}}{\mathrm{R}+\mathrm{L}} \times 100$ & $\frac{\mathrm{R} \sim \mathrm{L}}{\mathrm{R}+\mathrm{L}} \times 100$ \\
\hline $\begin{array}{l}\text { Rectus superior } \\
\text { Rectus medialis } \\
\text { Rectus lateralis } \\
\text { Rectus inferior } \\
\text { Obliquus superior } \\
\text { Obliquus inferior } \\
\text { Levator palp. sup. }\end{array}$ & $\begin{array}{l}\text { sq. } \mu \\
6 \mathrm{r.1} \\
69.2 \\
81.9 \\
87.5 \\
92.3 \\
94.4 \\
88.5\end{array}$ & $\begin{array}{r}\text { sq. } \mu \\
87.2 \\
87.8 \\
139.8 \\
100.9 \\
73.5 \\
70.3 \\
77.3\end{array}$ & $\begin{array}{r}\text { sq. } \mu \\
74.2 \\
78.5 \\
\text { xro.9 } \\
94.2 \\
82.9 \\
82.4 \\
82.9\end{array}$ & $\begin{array}{l}41.20 \% \\
44.08 \\
36.94 \\
46.44 \\
55.67 \\
57 \cdot 32 \\
53.38\end{array}$ & $\begin{array}{l}58.80 \% \\
55.92 \\
63.06 \\
53.56 \\
44.33 \\
42.68 \\
46.62\end{array}$ & $\begin{array}{l}17.60 \% \\
11.84 \\
26.12 \\
7.12 \\
11.34 \\
14.64 \\
6.76\end{array}$ \\
\hline Average & 82.1 & 91.0 & 86.6 & 47.86 & 52.14 & 13.63 \\
\hline Max. $\div$ Min & $x .55$ & $x .99$ & $\mathrm{x} .49$ & - & 一 & - \\
\hline
\end{tabular}

\section{Summary.}

To sum up the findings of the above measurement, the following interesting results are obtained. As already described, the most ocular muscles consist of two kinds of muscle fibres, namely the axial thick and the peripheral fine fibres. In the following the findings regarding the two kinds of muscle fibres are explained separately.

\section{Axial thick fibres.}

The area of the transverse section of the axial thick fibres, i.e., the size of the axial thick fibres in the ocular muscles varies, as represented in Table 22, not only according to muscles, but also with individuals and the bodysides to which the muscles belong. It is in the right Rectus medialis of case 9 ( $507.2 \mathrm{sq} . \mu)$ the greatest and in the left Rectus medialis of case 7 (97.8 sq. $\mu$ ) the smallest. The ratio of the greatest to the smallest value is $5.2: \mathrm{I}$. 
Table 22. Size of axial thick fibres in each case.

\begin{tabular}{|c|c|c|c|c|c|c|c|c|c|c|}
\hline \multicolumn{2}{|c|}{$\begin{array}{l}\text { Case and } \\
\text { body-side }\end{array}$} & Rs & $\mathrm{Rm}$ & $\mathrm{RI}$ & $\mathrm{Ri}$ & Os & $\mathrm{Oi}^{\prime}$ & Lps & Average & $\frac{\text { Max. }}{\text { Min. }}$ \\
\hline I & $\begin{array}{l}r \\
1\end{array}$ & $\begin{array}{l}\text { sq. } \mu \\
I 42 . I \\
200.1\end{array}$ & $\begin{array}{l}\text { sq. } \mu \\
\text { I } 52.3 \\
\text { I02.0 }\end{array}$ & $\begin{array}{r}\text { sq. } \mu \\
I 84.8 \\
I 10.9\end{array}$ & $\begin{array}{l}\text { sq. } \mu \\
\text { I } 52.0 \\
\text { I } 08.2\end{array}$ & $\begin{array}{l}\text { sq.e } \\
\text { I35.0 } \\
\text { I } 8 \mathrm{I} .3\end{array}$ & $\begin{array}{l}\text { sq. } \mu \\
\text { I } 17.9 \\
\text { I } 90.9\end{array}$ & $\begin{array}{r}\text { sq. } \mu \\
I 72.9 \\
I 40.7\end{array}$ & $\begin{array}{l}\text { sq. } \mu \\
\text { I } 5 \text { I. } \\
\text { I } 47.7\end{array}$ & $\begin{array}{l}1.57 \\
1.96\end{array}$ \\
\hline 2 & $\begin{array}{l}r \\
1\end{array}$ & $\begin{array}{l}205.9 \\
167.1\end{array}$ & $\begin{array}{l}200.8 \\
174.9\end{array}$ & $\begin{array}{l}222.2 \\
\times 41.9\end{array}$ & $\begin{array}{l}300.1 \\
125.0\end{array}$ & $\begin{array}{l}I 22.5 \\
226.6\end{array}$ & $\begin{array}{l}232.2 \\
183.1\end{array}$ & $\begin{array}{l}189.1 \\
163.2\end{array}$ & $\begin{array}{l}210.4 \\
168.8\end{array}$ & $\begin{array}{l}2.45 \\
1.8 \mathrm{I}\end{array}$ \\
\hline 3 & $\begin{array}{l}t \\
1\end{array}$ & $\begin{array}{l}190.4 \\
278.5\end{array}$ & $\begin{array}{l}195.3 \\
217.8\end{array}$ & $\begin{array}{l}149.0 \\
202.6\end{array}$ & $\begin{array}{l}152.0 \\
216.5\end{array}$ & $\begin{array}{l}176.4 \\
209.4\end{array}$ & $\begin{array}{l}307.4 \\
215.6\end{array}$ & $\begin{array}{l}163.2 \\
214.9\end{array}$ & $\begin{array}{l}190.5 \\
213.6\end{array}$ & $\begin{array}{l}2.06 \\
1.08\end{array}$ \\
\hline 4 & $\begin{array}{l}r \\
1\end{array}$ & $\begin{array}{l}296.7 \\
368.7\end{array}$ & $\begin{array}{l}225.8 \\
272.4\end{array}$ & $\begin{array}{l}244 \cdot 9 \\
280.3\end{array}$ & $\begin{array}{l}173.1 \\
211.0\end{array}$ & $\begin{array}{l}145.8 \\
\times 86.0\end{array}$ & $\begin{array}{l}\text { I 84.3 } \\
\text { I91.0 }\end{array}$ & $\begin{array}{l}183.4 \\
216.5\end{array}$ & $\begin{array}{l}207.7 \\
246.6\end{array}$ & $\begin{array}{l}2.03 \\
1.98\end{array}$ \\
\hline 5 & $\begin{array}{l}r \\
1\end{array}$ & $\begin{array}{l}320.8 \\
244.8\end{array}$ & $\begin{array}{l}302.1 \\
309.6\end{array}$ & $\begin{array}{l}335.5 \\
303.8\end{array}$ & $\begin{array}{l}366.0 \\
297.5\end{array}$ & $\begin{array}{l}363.8 \\
287.1\end{array}$ & $\begin{array}{l}401.6 \\
289.6\end{array}$ & $\begin{array}{l}403.1 \\
173.3\end{array}$ & $\begin{array}{l}356.1 \\
272.2\end{array}$ & $\begin{array}{l}1.33 \\
1.79\end{array}$ \\
\hline 6 & $\begin{array}{l}r \\
1\end{array}$ & $\begin{array}{l}\text { I4 I.I } \\
\text { II } 3.1\end{array}$ & $\begin{array}{l}\text { I I I.I } \\
\text { I S } 0.3\end{array}$ & $\begin{array}{l}142.6 \\
187.5\end{array}$ & $\begin{array}{l}104.9 \\
x 88.1\end{array}$ & $\begin{array}{l}122.7 \\
196.2\end{array}$ & $\begin{array}{l}106.3 \\
202.6\end{array}$ & $\begin{array}{l}109.4 \\
167.2\end{array}$ & $\begin{array}{l}1 \times 9.7 \\
172.1\end{array}$ & $\begin{array}{l}1.36 \\
1.79\end{array}$ \\
\hline 7 & $\begin{array}{l}r \\
1\end{array}$ & $\begin{array}{l}121.3 \\
117 \cdot 5\end{array}$ & $\begin{array}{r}116.9 \\
97.8\end{array}$ & $\begin{array}{l}141.7 \\
100.8\end{array}$ & $\begin{array}{r}\text { I } 10.5 \\
98.3\end{array}$ & $\begin{array}{l}126.4 \\
100.6\end{array}$ & $\begin{array}{r}108.5 \\
99.5\end{array}$ & $\begin{array}{l}128.6 \\
102.7\end{array}$ & $\begin{array}{l}122.0 \\
102.5 \\
\end{array}$ & $\begin{array}{l}I .3 I \\
I .20\end{array}$ \\
\hline 8 & $\begin{array}{l}r \\
1\end{array}$ & $\begin{array}{l}272.0 \\
216.5\end{array}$ & $\begin{array}{l}314.1 \\
285.0\end{array}$ & $\begin{array}{l}414 \cdot 0 \\
429.1\end{array}$ & $\begin{array}{l}391.3 \\
223.2\end{array}$ & $\begin{array}{l}375 \cdot 1 \\
282 \cdot 1\end{array}$ & $\begin{array}{l}382.7 \\
275.7\end{array}$ & $\begin{array}{l}374 \cdot 4 \\
256.3\end{array}$ & $\begin{array}{l}359.5 \\
281.1\end{array}$ & $\begin{array}{l}1.52 \\
1.98\end{array}$ \\
\hline 9 & $\begin{array}{l}r \\
1\end{array}$ & $\begin{array}{l}492.8 \\
357.6\end{array}$ & $\begin{array}{l}507.2 \\
438.6\end{array}$ & $\begin{array}{l}490.0 \\
411.8\end{array}$ & $\begin{array}{l}419.5 \\
401.6\end{array}$ & $\begin{array}{l}449.6 \\
384.7\end{array}$ & $\begin{array}{l}228.9 \\
385.9\end{array}$ & $\begin{array}{l}470.7 \\
397.3\end{array}$ & $\begin{array}{l}437 \cdot I \\
397.8\end{array}$ & $\begin{array}{l}2.22 \\
1.23 \\
\end{array}$ \\
\hline Io & $\begin{array}{l}1 \\
1\end{array}$ & $\begin{array}{l}365.3 \\
308.1\end{array}$ & $\begin{array}{l}328.0 \\
286.6\end{array}$ & $\begin{array}{l}332.3 \\
365.4\end{array}$ & $\begin{array}{l}357.9 \\
325.5\end{array}$ & $\begin{array}{l}340.2 \\
227.3\end{array}$ & $\begin{array}{l}358.0 \\
269.3\end{array}$ & $\begin{array}{l}333.0 \\
216.3\end{array}$ & $\begin{array}{r}345.1 \\
285.5\end{array}$ & $\begin{array}{l}1.11 \\
1.69\end{array}$ \\
\hline A & & 243.0 & 239.4 & 259.6 & 236.1 & 232.0 & 236.6 & 228.8 & 239.4 & 1.67 \\
\hline
\end{tabular}

In this and the following tables.

Rs-Rectus superior, $\mathrm{Rm}$-Rectus medialis, $\mathrm{Rl-Rectus} \mathrm{lateralis,} \mathrm{Ri-Rectus} \mathrm{inferior,}$ Os-Obliquus superior, Oi-Obliquus inferior and Lps-Levator palpebrae superioris.

The proportion of the highest and lowest value of the size (max./min.) on one body-side lies between 1.08 (left side of case 3) and 2.45 (right side of case 2), corresponding to the average value of I.67. These figures indicate that among the ocular muscles on one body-side the variation of the size of axial thick fibres is of low degree. The proportion is on only 4 out of 20 sides of the body greater than 2.00 and on all body-sides it is smaller than 2.50.

As seen on Table 22, the average size of axial thick fibres in the same named muscles on 20 sides of the io fetuses is the greatest in Rectus lateralis, then come Rectus superior, Rectus medialis, Obliquus inferior etc., being the least in Levator palpebrae superioris.

I calculated on the basis of Table 22 the correlation coefficient between the size of axial thick fibres in the left and right same named muscles and obtained $\mathrm{r} \pm \mathrm{m}_{\mathbf{r}}=0.79 \pm 0.045$. From this it may be concluded that the right and left same named muscles show regarding the size of their axial thick fibres a high correlation between them.

As demonstrated in Table 23, the order of the size of axial thick fibres in the seven ocular muscles on one side of the body differs according to each side of the body and each individual. It is also found that all 20 bodysides differ respectively more or less in order and that no individual shows 
the same order on both sides. The correlation coefficient between the order number of the same named muscles on both sides is extremely small and comes up to only $0.03 \pm 0.119$.

Table 23. Order of the size of axial thick fibres in each case (body-side).

\begin{tabular}{|c|c|c|c|c|c|c|c|c|}
\hline \multicolumn{2}{|c|}{ Case and body-side } & Rs & $\mathrm{Rm}$ & $\mathrm{RI}$ & $\mathrm{Ri}$ & Os & $\mathrm{Oi}$ & Lps \\
\hline $\mathbf{I}$ & $\begin{array}{l}r \\
1\end{array}$ & $\begin{array}{l}5 \\
1\end{array}$ & $\begin{array}{l}3 \\
7 \\
\end{array}$ & $\begin{array}{r}1 \\
5 \\
\end{array}$ & $\begin{array}{l}4 \\
6 \\
\end{array}$ & $\begin{array}{l}6 \\
3 \\
\end{array}$ & $\begin{array}{l}7 \\
2 \\
\end{array}$ & $\begin{array}{l}2 \\
4 \\
\end{array}$ \\
\hline 2 & $\begin{array}{l}r \\
1\end{array}$ & $\begin{array}{l}4 \\
4 \\
\end{array}$ & $\begin{array}{l}5 \\
3\end{array}$ & $\begin{array}{r}3 \\
6 \\
\end{array}$ & $\begin{array}{l}\mathbf{I} \\
7 \\
\end{array}$ & $\begin{array}{l}7 \\
I \\
\end{array}$ & $\begin{array}{l}2 \\
2 \\
\end{array}$ & $\begin{array}{l}6 \\
5\end{array}$ \\
\hline 3 & $\begin{array}{l}r \\
1\end{array}$ & $\begin{array}{l}3 \\
1\end{array}$ & 2 & $\begin{array}{l}7 \\
7 \\
\end{array}$ & $\begin{array}{l}6 \\
3\end{array}$ & $\begin{array}{l}4 \\
6 \\
\end{array}$ & $\begin{array}{l}I \\
4\end{array}$ & $\begin{array}{l}5 \\
5\end{array}$ \\
\hline 4 & $\begin{array}{l}r \\
1\end{array}$ & I & $\begin{array}{l}3 \\
3\end{array}$ & $\begin{array}{l}2 \\
2\end{array}$ & $\begin{array}{l}6 \\
5\end{array}$ & 7 & $\begin{array}{l}4 \\
6 \\
\end{array}$ & $\begin{array}{l}5 \\
4 \\
\end{array}$ \\
\hline 5 & $\begin{array}{l}r \\
1\end{array}$ & $\begin{array}{l}6 \\
6\end{array}$ & $\begin{array}{l}7 \\
1\end{array}$ & $\begin{array}{l}5 \\
2\end{array}$ & $\begin{array}{l}3 \\
3\end{array}$ & $\begin{array}{l}4 \\
5\end{array}$ & $\begin{array}{l}2 \\
4\end{array}$ & $\begin{array}{l}I \\
7\end{array}$ \\
\hline 6 & $\begin{array}{l}r \\
1\end{array}$ & $\begin{array}{l}2 \\
7\end{array}$ & $\begin{array}{l}4 \\
6\end{array}$ & $\begin{array}{l}\text { I } \\
4\end{array}$ & $\begin{array}{l}7 \\
3\end{array}$ & $\begin{array}{l}3 \\
2\end{array}$ & $\begin{array}{l}6 \\
1\end{array}$ & .5 \\
\hline 7 & $\begin{array}{l}r \\
1\end{array}$ & $\begin{array}{l}4 \\
\mathrm{I}\end{array}$ & $\begin{array}{l}5 \\
7\end{array}$ & $\begin{array}{l}1 \\
3\end{array}$ & $\begin{array}{l}6 \\
6\end{array}$ & $\begin{array}{l}3 \\
4 \\
\end{array}$ & $\begin{array}{l}7 \\
5\end{array}$ & $\begin{array}{l}2 \\
2\end{array}$ \\
\hline 8 & $\begin{array}{l}r \\
1\end{array}$ & $\begin{array}{l}7 \\
7\end{array}$ & $\begin{array}{l}6 \\
2\end{array}$ & $\begin{array}{l}\mathbf{I} \\
\mathbf{I}\end{array}$ & $\begin{array}{l}2 \\
6 \\
\end{array}$ & $\begin{array}{l}4 \\
3 \\
\end{array}$ & $\begin{array}{l}3 \\
4 \\
\end{array}$ & 5 \\
\hline 9 & $\begin{array}{l}r \\
1\end{array}$ & $\begin{array}{l}2 \\
7\end{array}$ & $\begin{array}{l}\text { I } \\
\text { I }\end{array}$ & $\begin{array}{l}3 \\
2\end{array}$ & $\begin{array}{l}6 \\
3\end{array}$ & 5 & $\begin{array}{l}7 \\
5\end{array}$ & $\begin{array}{l}4 \\
4\end{array}$ \\
\hline ro & $\begin{array}{l}r \\
1\end{array}$ & $\begin{array}{l}1 \\
3\end{array}$ & $\begin{array}{l}7 \\
4 \\
\end{array}$ & $\begin{array}{l}6 \\
1 \\
\end{array}$ & $\begin{array}{l}3 \\
2 \\
\end{array}$ & $\begin{array}{l}4 \\
6 \\
\end{array}$ & $\begin{array}{l}2 \\
5\end{array}$ & $\begin{array}{l}5 \\
7\end{array}$ \\
\hline $\begin{array}{l}\text { Ave } \\
\text { ord }\end{array}$ & $\begin{array}{l}\text { the } \\
\text { ber }\end{array}$ & $3 \cdot 7$ & 4.0 & 3.1 & $4 \cdot 4$ & $4 \cdot 5$ & 4.0 & $4 \cdot 4$ \\
\hline
\end{tabular}

When the order number of the same named muscles on 20 body-sides is balanced, it is found that the number is in Rectus lateralis 3.I, in Rectus superior 3.7, in Rectus medialis and Obliquus inferior 4.0, in Rectus inferior and Levator palpebrae superioris 4.4 and in Obliquus superior 4.5 (Table 23). This order is almost in accordance with the order regarding the average value of the size itself, which leads to conclusion that the size of thick fibres is in general in Rectus group greater than in Obliquus group and Levator palpebrae superioris, although the difference between them is very small.

The right percentage, i.e., the percentage of the size of axial thick fibres in one right muscle to the sum of the size in the corresponding muscles on both sides $\left(\frac{R}{R+L} \times 100\right)$ is the greatest in the Rectus inferior of case $2(70.60 \%)$ and the smallest in the Levator palpebrae superioris of case $6(30.68 \%)$, showing an average value of $51.30 \pm 0.96 \%$. The right percentage greater than $50.00 \%$ is found in 7 muscle pairs of case 7 , in 6 pairs of case $2,5,9$ and 10 , in 5 pairs of case 8, in 4 pairs of case $x$ and in $x$ pair of case 3 and 6 . From this observation it is clear that in 42 out of 70 muscle pairs the right percêntage is higher than $50.00 \%$ and in 7 out of to cases it is in the majority of the 7 muscle pairs greater than $50.00 \%$. These facts indicate that those 
muscle pairs, of which the axial thick fibres in the right muscle have a greater size than that in the left muscle, are greater in number than those muscle pairs, of which the axial thick fibres in the left muscle show a greater size than that in the right muscle (Table 24).

Table 24. Right percentage in each case (axial thick fibres).

\begin{tabular}{|c|c|c|c|c|c|c|c|c|}
\hline Case & $\mathrm{Rs}$ & $\mathrm{Rm}$ & $\mathrm{R} 1$ & $\mathrm{Ri}$ & $\mathrm{Os}$ & $\mathrm{Oi}$ & Ips & Average \\
\hline $\mathrm{I}$ & $41.53 \%$ & $59.89 \%$ & $62.50 \%$ & $58.42 \%$ & $42.72 \%$ & $38.18 \%$ & $55.13 \%$ & $51.20 \%$ \\
2 & 55.20 & 53.45 & 61.03 & 70.60 & 35.09 & 55.91 & 53.68 & 54.99 \\
3 & 46.56 & 47.28 & 42.38 & 41.82 & 45.72 & 58.78 & 43.16 & 46.53 \\
4 & 44.59 & 45.32 & 46.63 & 45.07 & 43.94 & $49.1 \mathrm{I}$ & 45.91 & 45.80 \\
5 & 56.72 & 49.39 & 52.48 & 55.16 & 55.89 & 58.10 & 69.93 & $56.8 \mathrm{I}$ \\
6 & 55.51 & 42.50 & 43.20 & 35.80 & 38.48 & 34.41 & 30.68 & 40.08 \\
7 & 50.80 & 54.45 & 58.43 & 52.92 & 55.68 & 52.16 & 55.60 & 54.29 \\
8 & 55.68 & $52.4 \mathrm{r}$ & 49.10 & 63.68 & 57.08 & 38.13 & 59.36 & 56.49 \\
9 & 57.95 & 53.63 & 54.34 & $5 \mathrm{r} .09$ & 53.89 & 37.23 & 54.23 & 51.77 \\
I0 & 54.25 & 53.37 & 47.63 & 52.37 & 59.95 & 57.07 & 60.62 & 55.04 \\
\hline Average & 51.88 & 51.17 & 51.77 & 52.69 & 48.84 & 47.91 & 52.83 & $* 51.30$ \\
\hline
\end{tabular}

* $\mathrm{M} \pm \mathrm{m}$ is in the right percentage $5 \mathrm{r} .30 \pm 0.96 \%$ and in the left $48.70 \pm 0.96 \%$.

The average value of the right percentage in each case is in case $5(56.81 \%)$ the highest, then come case $8,10,2,7,9,1,3$ and 4 , being the lowest in case $6(40.08 \%)$. In the latter 3 cases it is lower than $50.00 \%$.

Rectus superior, Rectus inferior and Levator palpebrae superioris show the right percentage over $50.00 \%$ in 7 out of ro cases, Rectus medialis in 6 cases and Rectus lateralis, Obliquus superior and Obliquus inferior in 5 cases. From this we see that in 4 out of 7 kinds of ocular muscles the right percentage is in the majority of 10 cases greater than $50.00 \%$. The average value of the right percentage in each kind of muscles is the highest in Levator palpebrae superioris $(52.83 \%)$, followed in order by. Rectus inferior, Rectus superior, Rectus lateralis etc., Obliquus inferior represents the lowest (47.9I\%) and in two kinds of muscle the average value is lower than $50.00 \%$, as indicated in Table 24.

The average value of the right and left percentage in all examined muscle pairs is $51.30 \pm 0.96 \%$ and $48.70 \pm 0.96 \%$. There is no significant difference between the right and left averaged percentage, so that it may be said that between the right and left muscles no significant difference regarding the size of axial thick fibres is found.

The difference between the right and left percentage $\left(\frac{R \sim L}{R+L} \times 100\right)$ shows the extent of the difference in size of axial thick fibres between the right 
and left same named muscles compared with the sum of the size of axial thick fibres in the two muscles. The smaller this difference is, the higher is the similarity in the size of axial thick fibres in the same named muscles on both sides. Among the total 70 muscle pairs the difference varies from $1.22 \%$ (Rectus medialis of case s) to $4 \mathrm{I} .20 \%$ (Rectus inferior of case 2). The difference lower than $10.00 \%$ show five pairs in case 4 and 9 , four pairs in case 7 and 10, three pairs in case 3 , two pairs in case 2, 5 and 8, and no pair in case $I$ and 6 . Accordingly, in 27 out of 70 muscle pairs this difference is smaller than $10.00 \%$. Presuming that in the muscle pairs with a difference lower than $10.00 \%$ the size of axial thick fibres in the right and left same named muscles are closely related each other, it might be said that in 27 out of 70 pairs the size of axial thick fibres in the right and left muscles resemble each other and that in the majority of the seven muscle pairs, the size of thick fibres in the same named muscles on both sides is in 4 out of rocases similar (Table 25).

The average value of the difference between the right and left percentage in each case is the greatest in case $6(22.98 \%)$ and the smallest in case $4(8.41 \%)$. It is smaller than $10.00 \%$ in case 4 and 7 .

In 7 kinds of ocular muscles the average difference is the smallest in Rectus medialis ( $8.54 \%$ ), then coome Rectus superior, Rectus lateralis etc., and the greatest in Levator palpebrae superioris (17.75\%). From this it becomes clear that the size of axial thick fibres in the left and right same named muscles is in Rectus group generally more similar than in Obliquus group and Levator palpebrae superioris (Table 25).

Table 25. Difference between the right and left percentage in each case (axial thick fibres).

\begin{tabular}{|c|c|c|c|c|c|c|c|c|}
\hline Case & Rs & $\mathrm{Rm}$ & Rl & $\mathbf{R i}$ & Os & $\mathrm{Oi}$ & Lps & Average \\
\hline I & I $6.94 \%$ & $19.78 \%$ & $25.00 \%$ & $16.84 \%$ & $14.56 \%$ & $23.64 \%$ & $10.26 \%$ & $18.15 \%$ \\
\hline 2 & $10.4^{\circ}$ & 6.90 & 22.06 & 41.20 & 29.82 & I $\mathrm{X} .82$ & 7.36 & $18.5 \mathrm{I}$ \\
\hline 3 & 6.88 & 5.44 & 15.24 & 16.36 & 8.56 & 17.56 & 13.60 & 11.95 \\
\hline 4 & xo.82 & $9 \cdot 36$ & 6.74 & 9.86 & I 2.12 & 1.78 & 8.18 & $8.4 \mathrm{I}$ \\
\hline$s$ & 13.44 & I.22 & 4.96 & 10.32 & II. 78 & 16.20 & 39.86 & 13.97 \\
\hline 6 & $1 \mathrm{x} .02$ & $\times 5.00$ & 13.60 & 28.40 & 23.04 & 31.18 & 38.64 & 22.98 \\
\hline 7 & 1.60 & 8.90 & 16.86 & 5.84 & II.36 & 4.32 & II. 20 & 8.58 \\
\hline 8 & Y 1.36 & 4.82 & $\mathrm{r} .80$ & 27.36 & 14.16 & 16.26 & 18.72 & 13.50 \\
\hline 9 & 15.90 & 7.26 & 8.68 & 2.18 & $7 \cdot 7^{8}$ & 25.54 & 8.46 & 10.83 \\
\hline 10 & 8.50 & 6.74 & 4.74 & $4 \cdot 74$ & $x 9.90$ & 14.14 & 21.24 & II.43 \\
\hline Average & 10.69 & 8.54 & II.97 & I6.3I & 15.31 & 16.24 & 17.75 & ${ }^{*}{ }_{13} .83$ \\
\hline
\end{tabular}

* $\mathrm{M} \pm \mathrm{m}=13.83 \pm 1.07 \%$. 
The average value of this difference obtained in 70 examined muscle pairs is $13.83 \pm 1.07 \%$. From this it may be concluded that the extent of the difference of the size of axial thick fibres between the same named muscles on both sides corresponds in average to $13.83 \pm 1.07 \%$ of the sum of the size of axial thick fibres in the two muscles. But this figure expresses only the average value of the extent of the difference in size of axial thick fibres between the same named muscles on both sides, without any consideration in which of the left and right muscles the size of axial thick fibres is greater than the other. That there is a significant difference in the size of axial thick fibres between the corresponding muscles on both sides is not compatible with the above mentioned fact that there is no significant difference in size of axial thick fibres between the left and right same named muscles.

Presuming that the average value of the size of axial thick fibres in the right and left same named muscles in one individual $\left(\frac{R+L}{2}\right)$ represents the size of axial thick fibres in the corresponding muscles of the corresponding individual and presuming that the average value of the size of axial thick fibres in the same named muscles in individuals of the same sex and age presents the size in the corresponding muscles in the corresponding sex and age, the Table 26 was obtained.

Table 26. Size of axial thick fibres in each fetal month and sex.

\begin{tabular}{|c|c|c|c|c|c|c|c|c|c|c|}
\hline Sex & Age & Case & Rs & $\mathrm{Rm}$ & $\mathrm{Rl}$ & $\mathrm{R} !$ & Os & Qi & Lps & Average \\
\hline \multirow{4}{*}{ 今 } & $7 \mathrm{~m}$ & I & $\begin{array}{c}\text { sq. } \mu \\
171.1\end{array}$ & $\begin{array}{r}\text { sq. } \mu \\
127.2\end{array}$ & $\begin{array}{r}\text { sq. } \mu \\
x 47.9\end{array}$ & $\begin{array}{l}\text { sq. } \mu \\
\text { I } 30.1\end{array}$ & $\begin{array}{r}\text { sq. } \mu \\
x \leqslant 8.3\end{array}$ & $\begin{array}{c}\text { sq. } \mu \\
\text { Is } 4.4\end{array}$ & $\begin{array}{c}\text { sq. } \mu \\
156.8\end{array}$ & $\begin{array}{l}\text { sq. } \mu \\
149.4\end{array}$ \\
\hline & $8^{\prime \prime}$ & 3 & 204.5 & 206.6 & 175.8 & I 84.3 & 192.4 & 261.5 & 189.1 & 202.0 \\
\hline & $9^{\prime \prime}$ & 5 & 282.8 & 305.9 & 319.7 & 316.8 & 325.5 & 345.6 & 288.2 & 312.1 \\
\hline & 10" & 7,8 & I 81.9 & 386.3 & 436.3 & 359.0 & 372.9 & 285.4 & 374.7 & $364 \cdot 7$ \\
\hline \multirow{4}{*}{ 우 } & $7 \mathrm{~m}$ & 2 & I86.5 & 187.9 & $182 . \mathrm{I}$ & 212.6 & 174.6 & 207.7 & 176.3 & 189.7 \\
\hline & 81 & 4 & 332.7 & $249 \cdot 1$ & 262.6 & 192.6 & 165.9 & $\times 87.7$ & 199.8 & 227.2 \\
\hline & $9^{\prime \prime}$ & 6 & 127.1 & 130.7 & 165.6 & 146.5 & 159.5 & 154.5 & 178.3 & I5I.7 \\
\hline & 10" & 9,10 & 381.0 & 390.1 & 399.9 & 376.2 & 350.5 & 310.6 & 354.4 & 366.6 \\
\hline
\end{tabular}

In order to compare the size of axial thick fibres between the male and female fetuses at the same age, I calculated in each kind of muscle the proportion of the size between the male and female fetuses of the same age (male/female). These findings are represented in Table 27. In the $9^{\text {th }}$ month this proportion is in all kinds of ocular muscles higher than 1.00 , whereas in the $7^{\text {th }}$ and roth month all kinds of muscles and in the 8th month 5 out of 7 kinds of muscles show a difference lower than 1.00. The average value of this difference in each fetal month is only in the $9^{\text {th }}$ month greater than 1.00 
and that in all kinds of ocular muscles it is greater than I.00. From these findings it is apparent that the size of axial thick fibres is in the majority of cases in the ocular muscles of the female fetuses greater than in that of the male fetuses of the same age, though the male fetuses were in general better nourished and developed than the female fetuses of the same age, as shown in Table $\mathrm{I}$.

Table 27. Proportion of the size of axial thick fibres between the male and female fetuses of the same age ( $\hat{o} / \%$ ).

\begin{tabular}{|c|c|c|c|c|c|c|c|c|}
\hline Age & $\mathrm{Rs}$ & $\mathrm{Rm}$ & $\mathrm{Rl}$ & $\mathrm{Ri}$ & $\mathrm{Os}$ & $\mathrm{Oi}$ & $\mathrm{Lps}$ & Average \\
\hline $7 \mathrm{~m}$ & 0.92 & 0.68 & $0.8 \mathrm{I}$ & $0.6 \mathrm{I}$ & $0.9 \mathrm{I}$ & 0.74 & 0.89 & 0.79 \\
$8^{\prime \prime}$ & $0.6 \mathrm{I}$ & 0.83 & 0.67 & 0.96 & $\mathrm{I} .16$ & $\mathrm{I} .39$ & 0.95 & 0.94 \\
$9^{\prime \prime}$ & $\mathbf{2 . 2 2}$ & 2.34 & $\mathrm{x} .94$ & 2.26 & 2.04 & $\mathbf{2 . 2 4}$ & $\mathrm{1} .62$ & 2.09 \\
$\mathrm{x} 0^{\prime \prime}$ & 0.47 & 0.52 & 0.68 & 0.55 & 0.63 & 0.70 & $0.6 \mathrm{I}$ & 0.59 \\
\hline Average & $\mathrm{I} .06$ & $\mathrm{I} .09$ & $\mathrm{I} .03$ & $\mathrm{I} .10$ & $\mathrm{I} .19$ & $\mathrm{I} .27$ & $\mathrm{I} .02$ & $\mathrm{I} .10$ \\
\hline
\end{tabular}

Supposing that the average value of the size of axial thick fibres in all the same named muscles in fetuses of the same age represents the size of the fibres in the corresponding muscles of the corresponding age, the Table 28 was obtained. This Table shows that the size of axial thick fibres in Rectus superior is in the 9th month the greatest and that in the other 6 kinds of muscles is in the roth month the highest, while that in all kind of muscles is in the 7 th month the smallest. The average value of the size in each month is the lowest in the $7^{\text {th }}$ month, then come the 8th and 9 th month and the highest in the roth month.

Table 28. Size of axial thick fibres in each fetal month.

\begin{tabular}{|c|c|c|c|c|c|c|c|c|c|}
\hline Age & Case & Rs & $\mathrm{Rm}$ & Rl & $\mathrm{Ri}$ & Os & Oi & Lps & Average \\
\hline $7 \mathrm{~m}$ & $x, 2$ & $\begin{array}{c}\text { sq. } \mu \\
\text { I } 78.8\end{array}$ & $\begin{array}{l}\text { sq. } \mu \\
157.5\end{array}$ & $\begin{array}{r}\text { sq. } \mu \\
x 65.0\end{array}$ & $\begin{array}{c}\text { sq. } \mu \\
171.4\end{array}$ & $\begin{array}{r}\text { sq. } \mu \\
\times 66.4\end{array}$ & $\begin{array}{l}\text { sq. } \mu \\
\text { r8I.I }\end{array}$ & $\begin{array}{c}\text { sq. } \mu \\
\text { I66.5 }\end{array}$ & $\begin{array}{c}\text { sq. } \mu \\
169.5\end{array}$ \\
\hline $8 \prime \prime$ & 3,4 & 268.6 & 227.9 & 219.2 & r88.2 & $\times 79.4$ & 224.6 & I94.6 & 214.6 \\
\hline $9^{\prime \prime}$ & 5,6 & 283.2 & 218.3 & 242.4 & 239.2 & 242.5 & 250.1 & 233.3 & 244.I \\
\hline $10 "$ & $7,8,9,10$ & $28 \mathrm{r} \cdot 4$ & 296.8 & 335.7 & 291.0 & 285.8 & 263.6 & 284.9 & $29 \mathrm{I} .3$ \\
\hline
\end{tabular}

According to Kato (1938), the size of axial thick fibres in the ocular muscles of a newborn baby is smaller than that of my ro months fetuses (4 cases, 8 body-sides), as shown in Table 29. It is probably that this is caused by the individual fluctuation. Among my to months fetuses, there is a case 
(case 7). which possesses nearly the same size as the newborn baby of Kato, whereas the other 3 cases have all thicker muscle fibres than the newborn baby.

Table 29. Size of axial thick fibres.

\begin{tabular}{|l|c|c|}
\hline Muscles & $\begin{array}{c}\text { Ka to } \\
\text { (Newborn baby) }\end{array}$ & $\begin{array}{c}\text { Hay a s hi } \\
\text { (10 months fetuses) }\end{array}$ \\
\hline Rectus superior & 152 sq. $\mu$ & 281.4 sq. $\mu$ \\
Rectus medialis & 219 & 296.8 \\
Rectus lateralis & 115 & 335.7 \\
Rectus inferior & 136 & 291.0 \\
Obliquus superior & 98 & 285.8 \\
Obliquus inferior & 174 & 263.6 \\
\hline
\end{tabular}

If the size of thick fibres in each ocular muscle in the 8th-1oth month is represented with the percentage against the size in the corresponding muscles in the 7 th month, the findings as in Table 30 are obtained. This Table indicates that the size of axial thick fibres has a tendency to increase with the age. In the roth month the increase of the size reaches about $145-200 \%$ of the size in the $7_{\text {th }}$ month.

Table 30. Proportion of the size of axial thick fibres in each fetal month.

\begin{tabular}{|c|c|c|c|c|c|c|c|}
\hline Age & Rs & Rm & Rl & Ri & Os & Oi & Lps \\
\cline { 1 - 3 } & 100 & 100 & 100 & 100 & 100 & 100 & 100 \\
$8 \prime \prime$ & 150 & 145 & 133 & 110 & 108 & 124 & 127 \\
$9 \prime \prime$ & 158 & 139 & 147 & 140 & 146 & 138 & 144 \\
$10 \prime \prime$ & -157 & 188 & 203 & 170 & 172 & 146 & 172 \\
\hline
\end{tabular}

\section{Peripheral fine fibres.}

The size of peripheral fine muscle fibres is in the left Rectus superior of case 9 (199.2 sq. $\mu$ ) the greatest and in the left Rectus lateralis of case I ( 34.7 sq. $\mu$ ) the smallest. The ratio of the former to the latter is $5.7: \mathrm{I}$. The proportion between the highést and lowest value on one body-side varies from 1.07 (right side of case 3 ) to 2.12 (left side of case 1 ); its average value comes up to $\mathrm{I} .4 \mathrm{r}$, which is somewhat smaller than that in axial thick fibres. The proportion is on all sides of the body smaller than 2.15 and on only $x$ out of 20 sides greater than 2.00 (Table $3 \mathrm{I}$ ). These facts indicate that the variation of the size of peripheral fine fibres among 7 ocular muscles on one body-side is very small and smaller than that of the axial thick fibres. 
Table 31. Size of peripheral fine fibres in each case.

\begin{tabular}{|c|c|c|c|c|c|c|c|c|c|c|}
\hline \multicolumn{2}{|c|}{$\begin{array}{l}\text { Case and } \\
\text { body-side }\end{array}$} & Rs & $\mathrm{Rm}$ & R1 & $\mathbf{R i}$ & Os & Oi & Lps & Average & $\frac{\text { Max. }}{\text { Min. }}$ \\
\hline I & $\begin{array}{l}r \\
1\end{array}$ & $\begin{array}{l}\text { sq. } \mu \\
71.5 \\
66.6\end{array}$ & $\begin{array}{l}\text { sq. } \mu \\
53.7 \\
62.2\end{array}$ & $\begin{array}{l}\text { sq. } \mu \\
47.1 \\
34.7\end{array}$ & $\begin{array}{l}\text { sq. } \mu \\
40.0 \\
\text { } 1.2\end{array}$ & $\begin{array}{l}\text { sq. } \mu \\
42.8 \\
73.6\end{array}$ & $\begin{array}{l}\text { sq. } \mu \\
41.4 \\
60.6\end{array}$ & $\begin{array}{l}\text { sq. } \mu \\
59.3 \\
44.8\end{array}$ & $\begin{array}{l}\text { sq. } \mu \\
50.8 \\
56.2 \\
\end{array}$ & $\begin{array}{l}1.79 \\
2.12 \\
\end{array}$ \\
\hline 2 & $\begin{array}{l}\mathbf{r} \\
1\end{array}$ & $\begin{array}{r}83.4 \\
110.9\end{array}$ & $\begin{array}{l}86.8 \\
90.0\end{array}$ & $\begin{array}{r}100.6 \\
92.7\end{array}$ & $\begin{array}{r}87.4 \\
100.0\end{array}$ & $\begin{array}{r}90.4 \\
106.7\end{array}$ & $\begin{array}{r}88.9 \\
x 09.0\end{array}$ & $\begin{array}{r}83.3 \\
101.6\end{array}$ & $\begin{array}{r}88.7 \\
101.6\end{array}$ & $\begin{array}{l}\text { I.2 I } \\
\text { I.23 }\end{array}$ \\
\hline 3 & $\begin{array}{l}r \\
1\end{array}$ & $\begin{array}{l}65.5 \\
72.1\end{array}$ & $\begin{array}{l}59.4 \\
62.1\end{array}$ & $\begin{array}{l}6 \mathrm{r} .5 \\
69.4\end{array}$ & $\begin{array}{l}58.6 \\
64.0\end{array}$ & $\begin{array}{l}57.8 \\
68.5\end{array}$ & $\begin{array}{l}65.8 \\
69.1\end{array}$ & $\begin{array}{l}64 \cdot 3 \\
72.1\end{array}$ & $\begin{array}{l}6 \mathrm{r} .8 \\
68.2\end{array}$ & $\begin{array}{l}1.07 \\
1.16\end{array}$ \\
\hline 4 & $\begin{array}{l}r \\
1\end{array}$ & $\begin{array}{l}61.4 \\
67.8 \\
\end{array}$ & $\begin{array}{l}69.9 \\
72.4 \\
\end{array}$ & $\begin{array}{r}59.3 \\
65.9 \\
\end{array}$ & $\begin{array}{l}64 \cdot 3 \\
67 \cdot 7 \\
\end{array}$ & $\begin{array}{l}80.8 \\
67.2 \\
\end{array}$ & $\begin{array}{l}80.8 \\
65.6 \\
\end{array}$ & $\begin{array}{l}75.4 \\
66.4 \\
\end{array}$ & $\begin{array}{l}70.3 \\
66.1\end{array}$ & $\begin{array}{l}\mathrm{x} .36 \\
\mathrm{x} .10 \\
\end{array}$ \\
\hline 5 & $\begin{array}{l}r \\
1\end{array}$ & $\begin{array}{r}103.4 \\
99.1\end{array}$ & $\begin{array}{r}90.0 \\
100.1\end{array}$ & $\begin{array}{r}96.4 \\
106.8\end{array}$ & $\begin{array}{r}95.9 \\
107.5\end{array}$ & $\begin{array}{l}101.7 \\
103.4\end{array}$ & $\begin{array}{l}94 \cdot 4 \\
95 \cdot 7\end{array}$ & $\begin{array}{l}99.0 \\
99.2\end{array}$ & $\begin{array}{r}97.3 \\
101.7\end{array}$ & $\begin{array}{l}\text { I.IS } \\
\text { I.I } 2\end{array}$ \\
\hline 6 & $\begin{array}{l}\mathbf{r} \\
1\end{array}$ & $\begin{array}{l}73.6 \\
81.8\end{array}$ & $\begin{array}{l}71.3 \\
78.2\end{array}$ & $\begin{array}{r}79.1 \\
118.9 \\
\end{array}$ & $\begin{array}{l}77 \cdot 4 \\
95 \cdot 7\end{array}$ & $\begin{array}{l}73.6 \\
95.0\end{array}$ & $\begin{array}{l}73.3 \\
94.0\end{array}$ & $\begin{array}{r}76.4 \\
104.4 \\
\end{array}$ & $\begin{array}{l}75.0 \\
95.4\end{array}$ & $\begin{array}{l}\text { I.II } \\
1.52 \\
\end{array}$ \\
\hline 7 & $\begin{array}{l}r \\
1\end{array}$ & $\begin{array}{r}107.5 \\
53.0\end{array}$ & $\begin{array}{l}59.2 \\
47.3\end{array}$ & $\begin{array}{l}83.4 \\
58.6\end{array}$ & $\begin{array}{l}75.4 \\
49 \cdot 7\end{array}$ & $\begin{array}{l}79.5 \\
48.9\end{array}$ & $\begin{array}{l}62.3 \\
58.0\end{array}$ & $\begin{array}{l}77 \cdot 9 \\
56.0\end{array}$ & $\begin{array}{l}77 \cdot 9 \\
53 \cdot 1\end{array}$ & $\begin{array}{l}\mathrm{I} .82 \\
\mathrm{r} .24 \\
\end{array}$ \\
\hline 8 & $\begin{array}{l}\mathbf{r} \\
1 .\end{array}$ & $\begin{array}{r}84.5 \\
104.4\end{array}$ & $\begin{array}{l}75.7 \\
99.6\end{array}$ & $\begin{array}{r}70.8 \\
116.0\end{array}$ & $\begin{array}{r}77.6 \\
104.1\end{array}$ & $\begin{array}{l}75.0 \\
96.0\end{array}$ & $\begin{array}{r}75.0 \\
101.2\end{array}$ & $\begin{array}{l}74 \cdot 1 \\
90.2\end{array}$ & $\begin{array}{r}7^{6.1} \\
101.6\end{array}$ & $\begin{array}{l}1.19 \\
1.29 \\
\end{array}$ \\
\hline 9 & $\begin{array}{l}\mathbf{r} \\
1\end{array}$ & $\begin{array}{r}97 \cdot 3 \\
199.2\end{array}$ & $\begin{array}{r}80.2 \\
122.8\end{array}$ & $\begin{array}{r}97.7 \\
\text { I } 18.6\end{array}$ & $\begin{array}{l}109.2 \\
108.1\end{array}$ & $\begin{array}{l}107.6 \\
107.5\end{array}$ & $\begin{array}{r}95.0 \\
x 09.8\end{array}$ & $\begin{array}{l}110.5 \\
105.3\end{array}$ & $\begin{array}{r}99.6 \\
\times 24.5\end{array}$ & $\begin{array}{l}\mathrm{I} .38 \\
\mathrm{I} .89\end{array}$ \\
\hline Io & $\begin{array}{l}\mathbf{r} \\
\mathbf{l}\end{array}$ & $\begin{array}{l}61.1 \\
87.2\end{array}$ & $\begin{array}{l}69.2 \\
87.8 \\
\end{array}$ & $\begin{array}{r}81.9 \\
139.8 \\
\end{array}$ & $\begin{array}{r}87.5 \\
100.9 \\
\end{array}$ & $\begin{array}{l}92.3 \\
73.5 \\
\end{array}$ & $\begin{array}{l}94 \cdot 4 \\
70 \cdot 3 \\
\end{array}$ & $\begin{array}{l}88.5 \\
77 \cdot 3 \\
\end{array}$ & $\begin{array}{l}82.1 \\
91.0 \\
\end{array}$ & $\begin{array}{l}1.55 \\
1.99 \\
\end{array}$ \\
\hline Ave & & 87.6 & $7^{6.9}$ & 85.0 & $8 \mathrm{r} \cdot \mathrm{x}$ & 82. $\mathrm{Y}$ & 80.2 & $8 \mathrm{I} \cdot 3$ & 82.0 & $I .41$ \\
\hline
\end{tabular}

The average size of peripheral fine fibres in the same named muscles on 20 sides of the ro fetuses is the greatest in Rectus superior, followed in order by Rectus lateralis, Obliquus superior, Levator palpebrae superioris etc., being the least in Rectus medialis (Table $3 \mathrm{I}$ ). This order differs more or less from that of the axial thick fibres.

The correlation toefficient between the size of periperal fine fibres in the left and right same named muscles is $0.58 \pm 0.079$, which indicates that the left and right same named muscles show regarding the size of their peripheral fine fibres a little high correlation between them.

As described in Table 32, the order of the size of peripheral fine fibres in the 7 ocular muscles on one side of the body differs according to each bodyside and each individual and there is no individual which shows the same order on both sides. The coefficient between the order number of the same named muscles on both sides is remarkably small and is $0.01 \pm 0.119$.

When the order number of the same named muscles on 20 body-sides is averaged, it is found that the averaged order number is in Rectus superior 3.2, in Rectus lateralis 3.5, in Obliquus superior 3.9, in Levator palpebrae superioris 4.0, in Rectus inferior 4.1, in Obliquus inferior 4.3 and in Rectus medialis 5.0 (Table 32). This order is quiet equal to that of the average value of the size itself. Although the size of axial thick fibres is in general 
Table 32. Order of the size of peripheral fine fibres in each case (body-side).

\begin{tabular}{|c|c|c|c|c|c|c|c|c|}
\hline \multicolumn{2}{|c|}{ Case and body-side } & Rs & $\mathrm{Rm}$ & Rl & $\mathbf{R i}$ & Os & Oi & Lps \\
\hline I & $\begin{array}{l}r \\
1\end{array}$ & $\begin{array}{l} \\
2\end{array}$ & $\begin{array}{l}3 \\
3\end{array}$ & $\begin{array}{l}4 \\
7\end{array}$ & $\begin{array}{l}7 \\
5\end{array}$ & 5 & $\begin{array}{l}6 \\
4 \\
\end{array}$ & $\begin{array}{l}2 \\
6 \\
\end{array}$ \\
\hline 2 & $\begin{array}{l}r \\
1\end{array}$ & $\begin{array}{l}6 \\
1 \\
\end{array}$ & $\begin{array}{l}5 \\
7\end{array}$ & $\begin{array}{l}x \\
6 \\
\end{array}$ & $\begin{array}{l}4 \\
5 \\
\end{array}$ & $\begin{array}{l}2 \\
3 \\
\end{array}$ & $\begin{array}{l}3 \\
2\end{array}$ & $\begin{array}{l}7 \\
4 \\
\end{array}$ \\
\hline 3 & $\begin{array}{l}r \\
1\end{array}$ & $\begin{array}{l}2 \\
1\end{array}$ & $\begin{array}{l}5 \\
7\end{array}$ & $\begin{array}{l}4 \\
3\end{array}$ & $\begin{array}{l}6 \\
6\end{array}$ & $\begin{array}{l}7 \\
5\end{array}$ & $\begin{array}{l} \\
4 \\
\end{array}$ & $\begin{array}{r}3 \\
1 \\
\end{array}$ \\
\hline 4 & $\begin{array}{l}r \\
1\end{array}$ & $\begin{array}{l}6 \\
2 \\
\end{array}$ & $\begin{array}{l}4 \\
\mathrm{I}\end{array}$ & $\begin{array}{l}7 \\
6\end{array}$ & $\begin{array}{l}5 \\
3\end{array}$ & $\begin{array}{l}1 \\
4 \\
\end{array}$ & $\begin{array}{l}x \\
7\end{array}$ & $\begin{array}{l}3 \\
5 \\
\end{array}$ \\
\hline 5 & $\begin{array}{l}r \\
1\end{array}$ & $\begin{array}{l}1 \\
6\end{array}$ & $\begin{array}{l}7 \\
4\end{array}$ & $\begin{array}{l}4 \\
2 \\
\end{array}$ & 5 & $\begin{array}{l}2 \\
3\end{array}$ & $\begin{array}{l}6 \\
7 \\
\end{array}$ & $\begin{array}{l}3 \\
5 \\
\end{array}$ \\
\hline 6 & $\begin{array}{l}\mathbf{r} \\
1\end{array}$ & $\begin{array}{l}4 \\
6 \\
\end{array}$ & $\begin{array}{l}7 \\
7\end{array}$ & $\begin{array}{l}I \\
I\end{array}$ & $\begin{array}{l}2 \\
3 \\
\end{array}$ & $\begin{array}{l}5 \\
4\end{array}$ & $\begin{array}{l}6 \\
5 \\
\end{array}$ & $\begin{array}{l}3 \\
2 \\
\end{array}$ \\
\hline 7 & $\begin{array}{l}r \\
1\end{array}$ & $\begin{array}{l} \\
4 \\
\end{array}$ & $\begin{array}{l}6 \\
7 \\
\end{array}$ & $\begin{array}{l}2 \\
1\end{array}$ & $\begin{array}{r}7 \\
5\end{array}$ & $\begin{array}{l}3 \\
6 \\
\end{array}$ & $\begin{array}{l}5 \\
2 \\
\end{array}$ & $\begin{array}{l}4 \\
3 \\
\end{array}$ \\
\hline 8 & $\begin{array}{l}r \\
1\end{array}$ & $\begin{array}{l}I \\
2\end{array}$ & $\begin{array}{l}3 \\
5 \\
\end{array}$ & $\begin{array}{l}7 \\
1 \\
\end{array}$ & $\begin{array}{l}2 \\
3 \\
\end{array}$ & $\begin{array}{l}4 \\
6 \\
\end{array}$ & $\begin{array}{l}4 \\
4 \\
\end{array}$ & $\begin{array}{l}6 \\
7 \\
\end{array}$ \\
\hline 9 & $\begin{array}{l}t \\
1\end{array}$ & $\begin{array}{l}5 \\
1\end{array}$ & $\begin{array}{l}7 \\
2\end{array}$ & $\begin{array}{l}4 \\
3\end{array}$ & $\begin{array}{l}2 \\
5\end{array}$ & 3 & $\begin{array}{l}6 \\
4\end{array}$ & $\begin{array}{l}1 \\
7\end{array}$ \\
\hline 10 & $\begin{array}{l}\mathbf{r} \\
1\end{array}$ & $\begin{array}{l}7 \\
4 \\
\end{array}$ & $\begin{array}{l}6 \\
3\end{array}$ & $\begin{array}{l}5 \\
1 \\
\end{array}$ & $\begin{array}{l}4 \\
2 \\
\end{array}$ & $\begin{array}{l}2 \\
6 \\
\end{array}$ & $\begin{array}{l}I \\
7\end{array}$ & $\begin{array}{l}3 \\
5 \\
\end{array}$ \\
\hline $\begin{array}{l}\text { Avera } \\
\text { order }\end{array}$ & $\begin{array}{l}\text { the } \\
\text { ber }\end{array}$ & 3.2 & 5.0 & 3.5 & $4 \cdot x$ & 3.9 & 4.3 & 4.0 \\
\hline
\end{tabular}

in Rectus group greater than in the other muscles, the size of peripheral fine fibres does not show such a relation.

The proportion of size between the peripheral fine and axial thick fibres in an ocular muscle varies, as indicated in Table 33, from I.I (right Rectus superior of case 8) to 6.3 (right Rectus medialis of case 9), corresponding the average value of 3.0. It is in 6 out of 140 muscles lower than 1.5 and in 22 muscles over 4.0. The average value of this proportion on one body-side lies between I.6 (left side of case 2 and right side of case 6 and 8) and 4.8 (right side of case 7); it varies with cases, but on both sides of one and the same fetus it is in almost all fetuses almost similar. The average proportion in the same named muscles on 20 body-sides is in Rectus medialis and Rectus lateralis 3.I, in Rectus superior and Obliquus inferior 3.0, in Rectus inferior 2.9 and in Obliquus superior and Levator palpebrae superioris 2.8. From this it becomes clear that the proportion is in average in all kinds of ocular muscles almost the same and that the axial thick fibres are, in general, in all kinds of muscles about 3 times thicker than the peripheral fine fibres.

The right percentage is the greatest in the Rectus superior of case 7 $(66.98 \%)$ and the smallest in the Rectus superior of case $9(32.82 \%)$, showing an average value of $48.15 \pm 0.75 \%$. The right percentage greater than $50.00 \%$ is found in seven muscle pairs of case 7 , in three pairs of case $1,4,9$ and 10, 
Table 33. Proportion of size between the axiar thick and peripheral fine fibres.

\begin{tabular}{|c|c|c|c|c|c|c|c|c|c|c|}
\hline \multicolumn{2}{|c|}{$\begin{array}{l}\text { Case and } \\
\text { side of } \\
\text { the body }\end{array}$} & Rs & $\mathrm{Rm}$ & Rl & $\mathrm{Ri}$ & Os & $\mathrm{Oi}$ & Lps & Average & $\frac{\text { Max. }}{\text { Min. }}$ \\
\hline I & $\begin{array}{l}r \\
1\end{array}$ & $\begin{array}{l}2.0 \\
3.0\end{array}$ & $\begin{array}{l}2.8 \\
1.6\end{array}$ & $\begin{array}{l}3.9 \\
3.2\end{array}$ & $\begin{array}{l}3.8 \\
2.1\end{array}$ & $\begin{array}{l}3.2 \\
2.5\end{array}$ & $\begin{array}{l}2.8 \\
3.2\end{array}$ & $\begin{array}{l}2.9 \\
3.1\end{array}$ & $\begin{array}{l}3.1 \\
2.7 \\
\end{array}$ & $\begin{array}{r}1.95 \\
2.00 \\
\end{array}$ \\
\hline 2 & $\begin{array}{l}\mathbf{r} \\
1\end{array}$ & $\begin{array}{l}2.5 \\
1.5\end{array}$ & $\begin{array}{l}2.3 \\
1.9\end{array}$ & $\begin{array}{l}2.2 \\
1.5\end{array}$ & $\begin{array}{l}3.4 \\
1.2 \\
\end{array}$ & $\begin{array}{l}\text { I.4 } \\
\text { 2.1 }\end{array}$ & $\begin{array}{l}2.6 \\
1.7\end{array}$ & $\begin{array}{l}2.3 \\
1.6\end{array}$ & $\begin{array}{l}2.4 \\
\mathrm{r.6} \\
\end{array}$ & $\begin{array}{l}2.43 \\
1.75 \\
\end{array}$ \\
\hline 3 & $\stackrel{\mathbf{r}}{\mathbf{1}}$ & $\begin{array}{l}2.9 \\
3.0\end{array}$ & $\begin{array}{l}3.3 \\
3.5\end{array}$ & $\begin{array}{l}2.4 \\
2.9 \\
\end{array}$ & $\begin{array}{l}2.6 \\
3.4\end{array}$ & $\begin{array}{l}3.1 \\
3.1\end{array}$ & $\begin{array}{l}4 \cdot 7 \\
3.1\end{array}$ & $\begin{array}{l}2.5 \\
3.0 \\
\end{array}$ & $\begin{array}{l}3.1 \\
3.1 \\
\end{array}$ & $\begin{array}{l}1.96 \\
1.21 \\
\end{array}$ \\
\hline 4 & $\begin{array}{l}r \\
1\end{array}$ & $\begin{array}{l}4.8 \\
5.4\end{array}$ & $\begin{array}{l}3.2 \\
3.8\end{array}$ & $\begin{array}{l}4 \cdot I \\
4.3\end{array}$ & $\begin{array}{l}2.7 \\
3.1\end{array}$ & $\begin{array}{l}1.8 \\
2.8\end{array}$ & $\begin{array}{l}2.3 \\
2.9\end{array}$ & $\begin{array}{l}2.4 \\
3.3\end{array}$ & $\begin{array}{l}3.0 \\
3.7\end{array}$ & $\begin{array}{l}2.67 \\
1.93\end{array}$ \\
\hline 5 & $\begin{array}{l}r \\
1\end{array}$ & $\begin{array}{l}3.1 \\
2.5\end{array}$ & $\begin{array}{l}3.4 \\
3.1\end{array}$ & $\begin{array}{l}3.5 \\
2.8\end{array}$ & $\begin{array}{l}3.8 \\
2.8\end{array}$ & $\begin{array}{l}3.6 \\
2.8\end{array}$ & $\begin{array}{l}4.3 \\
3.0\end{array}$ & $\begin{array}{l}4.1 \\
1.7 \\
\end{array}$ & $\begin{array}{l}3.7 \\
2.7\end{array}$ & $\begin{array}{r}\mathrm{r} .39 \\
\mathrm{I} .82 \\
\end{array}$ \\
\hline 6 & $\begin{array}{l}r \\
1\end{array}$ & $\begin{array}{l}1.9 \\
1.4\end{array}$ & $\begin{array}{l}1.6 \\
1.9\end{array}$ & $\begin{array}{l}1.8 \\
1.6\end{array}$ & $\begin{array}{l}\mathrm{I} .4 \\
2.0\end{array}$ & $\begin{array}{l}\text { I.7 } \\
\text { 2.1 }\end{array}$ & $\begin{array}{l}1.5 \\
2.2\end{array}$ & $\begin{array}{l}\text { I. } 4 \\
\text { I.6 }\end{array}$ & $\begin{array}{l}1.6 \\
1.8 \\
\end{array}$ & $\begin{array}{l}1.36 \\
1.57\end{array}$ \\
\hline 7 & $\begin{array}{l}r \\
l\end{array}$ & $\begin{array}{l}3.2 \\
2.1 \\
\end{array}$ & $\begin{array}{l}4.1 \\
2.9 \\
\end{array}$ & $\begin{array}{l}5.8 \\
3.7\end{array}$ & $\begin{array}{l}5.0 \\
2.1\end{array}$ & $\begin{array}{l}5.0 \\
2.9 \\
\end{array}$ & $\begin{array}{l}5.1 \\
2.7\end{array}$ & $\begin{array}{l}5.1 \\
2.8 \\
\end{array}$ & $\begin{array}{l}4.8 \\
2.7 \\
\end{array}$ & $\begin{array}{l}1.81 \\
1.76 \\
\end{array}$ \\
\hline 8 & $\begin{array}{l}r \\
1\end{array}$ & $\begin{array}{l}1.1 \\
2.2\end{array}$ & $\begin{array}{l}2.0 \\
2.1\end{array}$ & $\begin{array}{l}1.7 \\
\text { I. }\end{array}$ & $\begin{array}{l}1.5 \\
2.0\end{array}$ & $\begin{array}{l}1.6 \\
2.1\end{array}$ & $\begin{array}{l}\text { I. } 7 \\
\text { I. } 7\end{array}$ & $\begin{array}{l}1.7 \\
1.8\end{array}$ & $\begin{array}{l}1.6 \\
1.9\end{array}$ & $\begin{array}{l}1.82 \\
1.29 \\
\end{array}$ \\
\hline 9 & $\begin{array}{l}r \\
1\end{array}$ & $\begin{array}{l}5.1 \\
1.8\end{array}$ & $\begin{array}{l}6.3 \\
3.6\end{array}$ & $\begin{array}{l}5.0 \\
3.5\end{array}$ & $\begin{array}{l}3.8 \\
3.7\end{array}$ & $\begin{array}{l}4.2 \\
3.6\end{array}$ & $\begin{array}{l}2.4 \\
3.5\end{array}$ & $\begin{array}{l}4.3 \\
3.8\end{array}$ & $\begin{array}{l}4.4 \\
3.4\end{array}$ & $\begin{array}{l}2.63 \\
2.11\end{array}$ \\
\hline 10 & $\begin{array}{l}r \\
1 \\
\end{array}$ & $\begin{array}{l}6.0 \\
3.5\end{array}$ & $\begin{array}{l}4.7 \\
3.3 \\
\end{array}$ & $\begin{array}{l}4 \cdot 1 \\
2.6 \\
\end{array}$ & $\begin{array}{l}4.1 \\
3.2\end{array}$ & $\begin{array}{l}3.7 \\
3.1 \\
\end{array}$ & $\begin{array}{l}3.8 \\
3.8 \\
\end{array}$ & $\begin{array}{l}3.8 \\
2.8 \\
\end{array}$ & $\begin{array}{l}4.3 \\
3.2 \\
\end{array}$ & $\begin{array}{l}1.62 \\
x .46\end{array}$ \\
\hline$A v$ & & 3.0 & 3.1 & 3.1 & 2.9 & 2.8 & 3.0 & 2.8 & 3.0 & $\mathrm{I} .83$ \\
\hline
\end{tabular}

one pair of case 2 and 5. From this it is clear that in 21 out of 70 muscle pairs the right percentage is greater than $50.00 \%$ and in only I out of Io cases it is in the majority of 7 muscle pairs higher than $50.00 \%$ (Table 34 ).

Table 34. Right percentage in each case (peripheral fine fibres).

\begin{tabular}{|c|c|c|c|c|c|c|c|c|}
\hline Case & $\mathrm{Rs}$ & $\mathrm{Rm}$ & $\mathrm{Rl}$ & $\mathrm{Ri}$ & $\mathrm{Os}$ & $\mathrm{Oi}$ & $\mathrm{Lps}$ & Average \\
\cline { 2 - 9 } $\mathrm{I}$ & $51.77 \%$ & $46.33 \%$ & $57.58 \%$ & $43.86 \%$ & $36.77 \%$ & $40.59 \%$ & $56.96 \%$ & $47.69 \%$ \\
2 & 42.92 & 49.10 & 52.04 & 46.64 & 45.87 & 44.92 & 45.05 & 46.65 \\
3 & 47.60 & 48.89 & 46.98 & 47.80 & 45.76 & 48.78 & 47.14 & $47.4 \mathrm{I}$ \\
4 & 47.52 & 49.12 & 47.36 & $48.7 \mathrm{I}$ & 54.59 & 55.19 & 53.17 & $50.8 \mathrm{x}$ \\
5 & 51.06 & 47.34 & 47.44 & 47.15 & 49.59 & 49.66 & 49.95 & 48.88 \\
6 & 47.36 & 47.69 & 39.95 & 44.56 & 43.65 & 43.81 & 42.26 & 44.18 \\
7 & 66.98 & 55.59 & 58.73 & 60.27 & 61.92 & 57.79 & 58.18 & 59.92 \\
8 & 44.73 & 43.18 & 37.90 & $42.7 \mathrm{I}$ & 43.86 & 42.57 & 45.10 & 42.86 \\
9 & 32.82 & $39.5 \mathrm{I}$ & 45.17 & 50.25 & 50.02 & 46.39 & 51.20 & 45.05 \\
I0 & 41.20 & 44.08 & 36.94 & 46.44 & 55.67 & 57.32 & 53.38 & 47.86 \\
\hline Average & 47.40 & 47.08 & 47.01 & 47.84 & 48.77 & 48.70 & 50.24 & $* 48.15$ \\
\hline
\end{tabular}

$* M_{ \pm m}$ is in the right percentage $48.15 \pm 0.75 \%$ and in the left percentage $51.85 \pm 0.75 \%$. 
The average value of the right percentage in each case is in case $7(59.92 \%)$ the highest, then come case $4,5,10,1,3,2,9$ and 6 , being the lowest (42.86\%) in case 8. In the former 2 cases it is higher than $50.00 \%$.

Levator palpebrae superioris shows the right percentage over $50.00 \%$ in 5 out of ro cases, Obliquus superior in 4 cases, Rectus superior, Rectus lateralis and Obliquus inferior in 3 cases, Rectus inferior in 2 cases and Rectus medialis in I case. The average value of the right percentage in each kind of muscles is the greatest in Levator palpebrae superioris ( $50.24 \%$ ), followed in order by Obliquus superior, Obliquus inferior, Rectus inferior etc., Rectus lateralis represents the lowest $(47.01 \%)$ and in 6 kinds of muscles the average value is lower than $50.00 \%$, as indicated in Table 34 .

The average value of the right and left percentage in all examined muscle pairs is $48.15 \pm 0.75 \%$. and $51.85 \pm 0.75 \%$. There is a significant difference between the right and left averaged percentage, so that it may be said that between the right and left muscles a significant difference regarding the size of peripheral fine fibres is found.

Among the total 70 muscle pairs the difference between the right and left percentage varies from $0.04 \%$ (Obliquus superior of case 9) to $34.36 \%$ (Rectus superior of case 9). The difference lower than $10.00 \%$ show seven pairs in case 3 and 5 , six pairs in case 4 , five pairs in case 2 and 9, two pairs in case 1,6 and 10, one pair in case 8 and no pair in case 7. Accordingly, in 37 out of 70 muscle pairs this difference is smaller than $10.00 \%$. Presuming that in the muscle pairs with a difference lower than $10.00 \%$ the size of peri-

Table 35. Difference between the right and left percentage in each case (peripheral fine fibres).

\begin{tabular}{|c|c|c|c|c|c|c|c|c|}
\hline Case & $\mathrm{Rs}$ & $\mathrm{Rm}$ & $\mathrm{Rl}$ & $\mathrm{Ri}$ & $\mathrm{Os}$ & $\mathrm{Oi}$ & Lps & Average \\
\hline $\mathrm{I}$ & $3.54 \%$ & $7.34 \%$ & $15.16 \%$ & $\mathrm{I2.28} \%$ & $26.46 \%$ & $18.82 \%$ & $13.92 \%$ & $13.93 \%$ \\
2 & 14.16 & $\mathrm{1} .80$ & 4.08 & 6.72 & 8.26 & 10.16 & 9.90 & 7.87 \\
3 & 4.80 & 2.22 & 8.04 & 4.40 & 8.48 & 2.48 & 5.72 & 5.16 \\
4 & 4.96 & 1.76 & 5.28 & 2.58 & 9.18 & 10.38 & 6.34 & 5.78 \\
5 & 2.12 & 5.32 & 5.12 & 5.70 & 0.82 & 0.68 & 0.10 & 2.84 \\
6 & 5.28 & 4.62 & 20.10 & 10.88 & 12.70 & 12.38 & 15.48 & 11.63 \\
7 & 33.96 & 11.18 & 17.46 & 20.54 & 23.84 & 15.58 & 16.36 & 19.85 \\
8 & 10.54 & 13.64 & 24.20 & 14.58 & 12.28 & 14.91 & 9.80 & 14.28 \\
9 & 34.36 & 20.98 & 9.66 & 1.50 & 0.04 & 7.22 & 2.40 & 10.88 \\
I0 & 17.60 & 11.84 & 26.12 & 7.12 & 11.34 & 14.64 & 6.76 & 13.63 \\
\hline Average & 13.13 & 8.07 & 13.52 & 8.63 & 11.34 & 10.73 & 8.68 & $*_{10.59}$ \\
\hline
\end{tabular}

* $\mathrm{M} \pm \mathrm{m}=\mathrm{r} 0.59 \pm 0.92 \%$. 
pheral fine fibres in the right and left same named muscles are closely related each other, it might be said that in 37 out of 70 pairs the size of the peripheral fine fibres in the right and left muscles resemble each other and that in five cases the right and left muscles show in the majority of seven muscle pairs similar, size of fine fibres (Table 35 ).

The average value of the difference between the right and left percentage in each case is the largest in case $7(19.85 \%)$ and the smallest in case $5(2.84 \%)$. It is smaller than $10.00 \%$ in case $2,3,4$ and 5 .

In seven kinds of ocular muscles the average difference is the largest in Rectus lateralis ( $13.52 \%$ ), then come Rectus superior, Obliquus superior etc., and the smallest in Rectus medialis (8.07\%).

The average value of this difference obtained in 70 examined muscle pairs is $10.59 \pm 0.92 \%$. From this it may be concluded that the extent of the difference of the size of peripheral fine fibres between the same named muscles on both sides corresponds in average to $10.59 \pm 0.92 \%$ of the sum of the size of peripheral fine fibres in the two muscles and that the difference seems here to be smaller than that of the axial thick fibres.

Presuming that the average value of the size of peripheral fine fibres in the right and left same named muscles in one individual $\left(\frac{R+L}{2}\right)$ represents the size of peripheral fine fibres in the corresponding muscles of the corresponding individual and presuming that the average value of the size of peripheral fine fibres in the same named muscles in individuals of the same sex and age presents the size in the corresponding muscles in the corresponding sex and age, the Table 36 was obtained.

Table ${ }_{3} 6$. Size of peripheral fine fibres in each fetal month and sex.

\begin{tabular}{|c|c|c|c|c|c|c|c|c|c|c|}
\hline Sex $\mid$ & Age & Case & Rs & $\mathrm{Rm}$ & $\mathrm{Rl}$ & $\mathbf{R i}$ & Os & $\mathrm{Oi}$ & Lps & Average \\
\hline \multirow{4}{*}{ 今 } & $7 \mathrm{~m}$ & I & $\begin{array}{c}-\mathrm{sq} . \mu \\
69 . \mathrm{I}\end{array}$ & $\begin{array}{l}\text { sq. } \mu \\
58.0\end{array}$ & $\begin{array}{l}\text { sq. } \mu \\
40.9\end{array}$ & $\begin{array}{r}\text { sq. } \mu \\
-45.0\end{array}$ & $\begin{array}{l}\text { sq. } \mu \\
58.2\end{array}$ & $\begin{array}{l}\text { sq. } \mu \\
\text { sx.0 }\end{array}$ & $\begin{array}{c}\text { sq. } \mu \\
\text { s2.I }\end{array}$ & $\begin{array}{l}\text { sq. } \mu \\
53.6\end{array}$ \\
\hline & $8 "$ & 3 & 68.8 & 60.8 & 65.5 & $6 x \cdot 3$ & 63.2 & 67.5 & 68.2 & 65.0 \\
\hline & $9^{\prime \prime}$ & 5 & 101.3 & 95.1 & 101.6 & 101.7 & 102.6 & 95.1 & $99 \cdot x$ & 99.5 \\
\hline & $10 "$ & 7,8 & $87 \cdot 4$ & 70.5 & 82.2 & 76.7 & 74.9 & $74 \cdot 2$ & $74 \cdot 6$ & $77 \cdot 2$ \\
\hline \multirow{4}{*}{ 우 } & $7 \mathrm{~m}$ & 2 & $97 \cdot 2$ & 88.4 & 96.7 & $93 \cdot 7$ & $9^{8.6}$ & 99.0 & 92.5 & 95.2 \\
\hline & $8^{\prime \prime}$ & 4 & $64 \cdot 6$ & $7^{1.2}$ & 62.6 & 66.0 & 74.0 & 73.2 & 70.9 & 68.9 \\
\hline & $9^{\prime \prime}$ & 6 & $77 \cdot 7$ & 74.8 & 99.0 & 86.9 & 84.3 & 83.7 & 90.4 & 85.3 \\
\hline & 10" & 9, I0 & $111 \cdot \dot{3}$ & 90.0 & 109.6 & IOI.S & 95.3 & 92.4 & 95.4 & $99 \cdot 4$ \\
\hline
\end{tabular}

In order to compare the size of peripheral fine fibres between the male and female fetuses at the same age, I calculated in each kind of muscle the proportion of the size between the male and female fetuses of the same age 
(male/female). These findings are represented in Table 37. In the $9^{\text {th }}$ month this proportion is in all kinds of ocular muscles higher than 1.00, while in the $7_{\text {th }}$ and roth month all kinds of muscles and in the 8th month $s$ out of 7 kinds of muscles show the difference lower than 1.00. The average value of this proportion in each fetal month is only in the $9^{\text {th }}$ month greater than 1.00 and in each kind of ocular muscle it is all lower than 1.00. From these findings it is apparent that the size of peripheral fine fibres is in the majority of cases in the ocular muscles of the female fetuses greater than in that of the male fetuses of the same age, though the male fetuses were in general better nourished and developed than the female fetuses of the same age, as shown in Table $r$.

Table 37. Proportion of the size of peripheral fine fibres between the male and female fetuses of the same age (스/우).

\begin{tabular}{|c|c|c|c|c|c|c|c|c|}
\hline Age & Rs & $\mathrm{Rm}$ & $\mathrm{Rl}$ & $\mathrm{Ri}$ & $\mathrm{Os}$ & $\mathrm{Oi}$ & Lps & Average \\
\hline $7 \mathrm{~m}$ & $0.7 \mathrm{x}$ & 0.66 & 0.42 & 0.49 & 0.59 & 0.52 & 0.56 & 0.56 \\
$8^{\prime \prime}$ & 1.07 & 0.85 & 1.05 & 0.93 & 0.85 & 0.92 & 0.96 & 0.95 \\
$9^{\prime \prime}$ & 1.30 & 1.27 & 1.17 & 1.22 & 1.22 & 1.14 & 1.10 & 1.20 \\
$10^{\prime \prime}$ & 0.79 & 0.78 & 0.75 & 0.76 & 0.79 & 0.80 & 0.78 & 0.77 \\
\hline Average & 0.97 & 0.89 & 0.85 & 0.85 & 0.87 & 0.85 & 0.85 & 0.87 \\
\hline
\end{tabular}

Supposing that the average value of the size of peripheral fine fibres in all the same named muscles in fetuses of the same age represents the size of the fine fibres in the corresponding muscles of the corresponding age, the Table 38 was obtained. This table shows that the size of peripheral fine fibres in Rectus superior is in the 8th month the smallest and in the roth month the greatest, whereas in the other 6 kinds of muscles in the 8th month the lowest and in the 9 th month the highest. The average value of the size in each month is the least in the 8th month, then come the 7 th and roth month and the greatest in the $9^{\text {th }}$ month.

Table 38. Size of peripheral fine fibres in each fetal month.

\begin{tabular}{|c|c|c|c|c|c|c|c|c|c|}
\hline Age & Case & Rs & $\mathrm{Rm}$ & RI & $\mathrm{Ri}$ & Os & Oi & Lps. & Average \\
\hline $7 \mathrm{~m}$ & I, 2 & $\begin{array}{c}\text { sq. } \mu \\
\text { 83.I }^{2}\end{array}$ & $\begin{array}{l}\text { sq. } \mu \\
73.1\end{array}$ & $\begin{array}{l}\text { sq. } \mu \\
68.8\end{array}$ & $\begin{array}{c}\text { sq. } \mu \\
69.7\end{array}$ & $\begin{array}{l}\text { sq. } \mu \\
78.4\end{array}$ & $\begin{array}{l}\text { sq. } \mu \\
75.0\end{array}$ & $\begin{array}{c}\text { sq. } \mu \mu \\
7^{2.3}\end{array}$ & $\begin{array}{l}\text { sq. } \mu \\
74.3\end{array}$ \\
\hline $8^{\prime \prime}$ & 3,4 & 66.7 & 66.0 & $64 \cdot 1$ & 63.7 & 68.6 & 70.4 & 69.6 & 67.0 \\
\hline $9^{\prime \prime}$ & 5,6 & 89.5 & 84.9 & 100.3 & 94.2 & 93.5 & 89.4 & 94.8 & 92.4 \\
\hline 10" & $7,8,9$, 10 & 99.3 & 80.3 & 95.9 & 89.1 & 85.1 & 83.3 & 85.0 & 88.3 \\
\hline
\end{tabular}

According to Kato (1938), the peripheral fine fibres in the ocular muscles of a newborn baby possess in general a similar size with those of my io months fetuses (4 cases, 8 body-sides), as demonstrated in Table 39. 
Table 39. Size of peripheral fine fibres.

\begin{tabular}{|l|c|c|}
\hline Muscles & $\begin{array}{c}\text { Kato } \\
\text { (Newborn baby) }\end{array}$ & $\begin{array}{c}\text { Ha y a s hi } \\
\text { (ro months fetuses) }\end{array}$ \\
\hline Rectus superior & 87 sq. $\mu$ & $99 \cdot 3$ sq. $\mu$ \\
Rectus medialis & $14 \mathrm{I}$ & 80.3 \\
Rectus lateralis & 60 & $95 \cdot 9$ \\
Rectus inferior & 90 & $89 . \mathrm{I}$ \\
Obliquus superior & 47 & $85 . \mathrm{I}$ \\
Obliquus inferior & $8 \mathrm{I}$ & 83.3 \\
\hline
\end{tabular}

If the size of peripheral fine fibres in each ocular muscle in the 8th-9th month is represented with the percentage against the size in the corresponding muscles in the $7^{\text {th }}$ month, the findings as in Table 40 are obtained. This table indicates that the size of peripheral fine fibres has a tendency to increase with the age. In the roth month the increase of the size reaches about I $10-140 \%$ of the size in the 7 th month. From this findings it may be concluded that the axial thick fibres in the ocular muscles increase in size more markedly with the age than the peripheral fine fibres.

Table 40. Proportion of the size of peripheral fine fibres in each fetal month.

\begin{tabular}{|c|c|c|c|c|c|c|c|}
\hline Age & $\mathrm{Rs}$ & $\mathrm{Rm}$ & $\mathrm{R} 1$ & $\mathrm{Ri}$ & Os & $\mathrm{Oi}$ & Lps \\
\hline $7 \mathrm{~m}$ & 100 & xoo & 100 & 100 & 100 & 100 & 100 \\
\hline $8 "$ & 80 & 90 & 93 & $9 \mathrm{I}$ & 88 & 93 & 96 \\
\hline $9^{\prime \prime}$ & 108 & $x 16$ & 146 & $\times 35$ & III & II & I3I \\
\hline $10 "$ & II & IXo & 139 & 128 & 108 & $\operatorname{IIX}$ & $x \times 8$ \\
\hline
\end{tabular}

If the size of the ocular muscles are divided by the number of muscle fibres, of which the muscles consist, the quotient indicates the presumptive size of muscle fibres in the ocular muscles, under the presumption that in the ocular muscles there exists no connective tissue and every muscle fibres have the same size. The Table $4 \mathrm{I}$ shows the presumptive size of muscle fibres in 7 kinds of ocular muscles in each body-side and the Table 42 indicates that in each fetal month. If the presumptive size of muscle fibres in each ocular muscle in the 8th-roth month is represented with the percentage against the size in the 7 th month, the findings as in Table 43 are obtained. From this table it is apparent that the presumptive size is in the 8th-roth month in the majority of cases slightly smaller than roo, which leads to the conclusion 
that the extent of increase of the number of muscle fibres is a little greater than that of the size of ocular muscles.

Table 4r. Presumptive size of muscle fibres.

\begin{tabular}{|c|c|c|c|c|c|c|c|c|c|c|}
\hline \multicolumn{2}{|c|}{$\begin{array}{l}\text { Case and } \\
\text { side of } \\
\text { the body }\end{array}$} & \multirow{2}{*}{\begin{tabular}{r}
\multicolumn{1}{c}{ Rs } \\
sq. $\mu$ \\
229.6 \\
238.4
\end{tabular}} & \multirow{2}{*}{$\begin{array}{l}\mathrm{Rm} \\
\text { sq.j } \\
23 \mathrm{I} \cdot 9 \\
\mathrm{I} 8 \mathrm{2.1}\end{array}$} & \multirow{2}{*}{$\begin{array}{c}\mathrm{Rl} \\
\mathrm{sq. \mu} \\
200.4 \\
\mathrm{x} 65.3\end{array}$} & \multirow{2}{*}{$\begin{array}{c}\mathrm{Ri} \\
\mathrm{sq} \cdot \mu \\
249.7 \\
219.4\end{array}$} & \multirow{2}{*}{$\begin{array}{c}\text { Os } \\
\text { sq. } \mu \\
205.8 \\
298.0\end{array}$} & \multirow{2}{*}{ 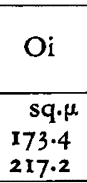 } & \multirow{2}{*}{$\begin{array}{r}\text { Lps } \\
\text { sq. } \mu \\
222.4 \\
I 77.9\end{array}$} & \multirow{2}{*}{\begin{tabular}{|c|} 
Average \\
$s q . \mu$ \\
216.2 \\
214.0 \\
\end{tabular}} & \multirow{2}{*}{$\begin{array}{c}\frac{\text { Max. }}{\text { Min. }} \\
\\
r .44 \\
1.80\end{array}$} \\
\hline I & $\begin{array}{l}\mathbf{r} \\
1\end{array}$ & & & & & & & & & \\
\hline 2 & $\begin{array}{l}r \\
1\end{array}$ & $\begin{array}{l}214 \cdot 1 \\
260.7 \\
\end{array}$ & $\begin{array}{l}204.8 \\
204.1 \\
\end{array}$ & $\begin{array}{l}241.8 \\
230.2 \\
\end{array}$ & $\begin{array}{l}199.0 \\
175.1\end{array}$ & $\begin{array}{l}233.9 \\
252.1\end{array}$ & $\begin{array}{l}320.4 \\
270.1 \\
\end{array}$ & $\begin{array}{l}240.6 \\
149.7 \\
\end{array}$ & $\begin{array}{l}236.4 \\
220.3 \\
\end{array}$ & $\begin{array}{l}1.6 \mathrm{I} \\
1.80 \\
\end{array}$ \\
\hline 3 & $\begin{array}{l}\mathbf{r} \\
1\end{array}$ & $\begin{array}{l}204 \cdot 2 \\
203.3\end{array}$ & $\begin{array}{l}127.8 \\
170.8\end{array}$ & $\begin{array}{l}207.8 \\
174.9\end{array}$ & $\begin{array}{l}174.0 \\
138.4\end{array}$ & $\begin{array}{l}165.9 \\
184.4\end{array}$ & $\begin{array}{l}206.3 \\
x 40.7\end{array}$ & $\begin{array}{l}265.0 \\
172.1 \\
\end{array}$ & $\begin{array}{l}193.0 \\
169.2\end{array}$ & $\begin{array}{r}2.07 \\
1.47 \\
\end{array}$ \\
\hline 4 & $\begin{array}{l}r \\
1\end{array}$ & $\begin{array}{l}209.8 \\
132.8\end{array}$ & $\begin{array}{l}168.7 \\
144.8\end{array}$ & $\begin{array}{l}231.3 \\
134.3\end{array}$ & $\begin{array}{l}185.0 \\
102.4\end{array}$ & $\begin{array}{l}155.0 \\
191.6\end{array}$ & $\begin{array}{l}247.9 \\
155.0\end{array}$ & $\begin{array}{l}231.4 \\
174.8 \\
\end{array}$ & $\begin{array}{l}204.2 \\
148.0 \\
\end{array}$ & $\begin{array}{r}1.60 \\
1.87 \\
\end{array}$ \\
\hline$s$ & $\begin{array}{l}r \\
1\end{array}$ & $\begin{array}{l}186.2 \\
x 60.1\end{array}$ & $\begin{array}{l}156.2 \\
196.0\end{array}$ & $\begin{array}{l}180.4 \\
201.2\end{array}$ & $\begin{array}{l}168.2 \\
175.0\end{array}$ & $\begin{array}{l}154.3 \\
141.5\end{array}$ & $\begin{array}{l}206.9 \\
217.8\end{array}$ & $\begin{array}{l}585.8 \\
226.7\end{array}$ & $\begin{array}{l}234.0 \\
188.3\end{array}$ & $\begin{array}{l}3.80 \\
x .60,\end{array}$ \\
\hline 6 & $\begin{array}{l}1 \\
\mathbf{r}\end{array}$ & $\begin{array}{r}226.7 \\
67.6 \\
\end{array}$ & $\begin{array}{r}196.9 \\
120.7\end{array}$ & $\begin{array}{l}176.8 \\
103.7\end{array}$ & $\begin{array}{l}129.4 \\
101.0\end{array}$ & $\begin{array}{l}161.1 \\
182.7\end{array}$ & $\begin{array}{l}279.1 \\
154.4\end{array}$ & $\begin{array}{l}229.1 \\
135.2\end{array}$ & $\begin{array}{r}199.9 \\
123.6\end{array}$ & $\begin{array}{l}2 . \times 6 \\
2.79\end{array}$ \\
\hline$\dot{7}$ & $\begin{array}{l}r \\
1\end{array}$ & $\begin{array}{l}121.0 \\
160.8 \\
\end{array}$ & $\begin{array}{l}68.8 \\
88.4\end{array}$ & $\begin{array}{r}88.8 \\
143.6\end{array}$ & $\begin{array}{r}76.8 \\
141.1\end{array}$ & $\begin{array}{l}101.1 \\
213.8\end{array}$ & $\begin{array}{r}96.5 \\
239.3\end{array}$ & $\begin{array}{l}127.6 \\
145.3\end{array}$ & $\begin{array}{r}97.2 \\
161.8\end{array}$ & $\begin{array}{l}1.85 \\
2.71\end{array}$ \\
\hline 8 & $\begin{array}{l}r \\
1\end{array}$ & $\begin{array}{l}154.4 \\
154.4\end{array}$ & $\begin{array}{l}167.4 \\
276.4\end{array}$ & $\begin{array}{l}209.7 \\
193.0\end{array}$ & $\begin{array}{l}137.3 \\
135.6\end{array}$ & $\begin{array}{l}209.6 \\
159.6\end{array}$ & $\begin{array}{l}315.7 \\
207.8\end{array}$ & $\begin{array}{l}258.1 \\
227.3\end{array}$ & $\begin{array}{l}207.5 \\
193.4\end{array}$ & $\begin{array}{l}2.30 \\
2.04\end{array}$ \\
\hline 9 & $\begin{array}{l}\mathbf{r} \\
\mathbf{l}\end{array}$ & $\begin{array}{l}347 \cdot 4 \\
294 \cdot 3\end{array}$ & $\begin{array}{l}266.6 \\
258.6\end{array}$ & $\begin{array}{l}417.6 \\
496.4\end{array}$ & $\begin{array}{l}278.5 \\
286.2\end{array}$ & $\begin{array}{l}261.2 \\
210.8\end{array}$ & $\begin{array}{l}385.6 \\
223.8\end{array}$ & $\begin{array}{l}328.8 \\
398.8\end{array}$ & $\begin{array}{l}326.5 \\
309.8\end{array}$ & $\begin{array}{l}1.60 \\
2.35\end{array}$ \\
\hline Io & $\begin{array}{l}t \\
1\end{array}$ & $\begin{array}{l}208.0 \\
203.6 \\
\end{array}$ & $\begin{array}{l}183.6 \\
200.0 \\
\end{array}$ & $\begin{array}{l}266.0 \\
277.5 \\
\end{array}$ & $\begin{array}{l}200.2 \\
218.6\end{array}$ & $\begin{array}{l}208.0 \\
183.7\end{array}$ & $\begin{array}{l}239.3 \\
270.8\end{array}$ & $\begin{array}{r}146.0 \\
163.7 \\
\end{array}$ & $\begin{array}{l}207.3 \\
216.8\end{array}$ & $\begin{array}{l}1.82 \\
1.70 \\
\end{array}$ \\
\hline Av & & 198.9 & 180.7 & 217.0 & 174.5 & I93.7 & 228.4 & 230.3 & 203.4 & $2.0 \mathrm{I}$ \\
\hline
\end{tabular}

Table 42. Presumptive size of muscle fibres in each fetal month.

\begin{tabular}{|c|c|c|c|c|c|c|c|c|c|}
\hline Age & Case & Rs & $\mathbf{R m}_{\mathrm{m}}$ & $\mathrm{R} 1$ & $\mathbf{R i}$ & Os & $\mathrm{Oi}$ & Lps & Average \\
\hline $7 \mathrm{~m}$ & $x, 2$ & $\begin{array}{r}s q . \mu \\
235.7\end{array}$ & $\begin{array}{r}\text { sq. } \mu \\
205.7\end{array}$ & $\begin{array}{r}\text { sq. } \mu \\
202.7\end{array}$ & $\begin{array}{l}\text { sq. } \mu \\
210.8\end{array}$ & $\begin{array}{l}\text { sq. } \mu \\
247.5\end{array}$ & $\begin{array}{l}\text { sq. } \mu \\
225.0\end{array}$ & $\begin{array}{c}\text { sq. } \mu \\
188.7\end{array}$ & $\begin{array}{r}\text { sq. } \mu \\
2 \times 6.7\end{array}$ \\
\hline $8^{\prime \prime}$ & 3,4 & 187.5 & 153.0 & 187.1 & 155.0 & 174.2 & 187.5 & 210.8 & 179.3 \\
\hline $9^{\prime \prime}$ & 5,6 & 160.2 & 167.5 & $x 65.5$ & 143.4 & I 59.9 & 214.6 & 294.2 & 186.5 \\
\hline Io" & $7,8,9 ; 10$ & 205.5 & x 88.7 & 261.6 & 184.3 & 193.5 & 247.4 & 224.5 & 215.1 \\
\hline \multicolumn{2}{|c|}{ Average } & 197.2 & 178.7 & 204.2 & 173.4 & 193.8 & $2 \times 8.6$ & 229.6 & I99.4 \\
\hline
\end{tabular}

Table 43. Proportion of the presumptive size of muscle fibres in each fetal month.

\begin{tabular}{|r|r|r|r|r|r|r|r|r|}
\hline Age & $\mathrm{Rs}$ & $\mathrm{Rm}$ & $\mathrm{Rl}$ & $\mathrm{Ri}$ & $\mathrm{Os}$ & $\mathrm{Oi}$ & Lps \\
\hline $7 \mathrm{~m}$ & 100 & 100 & 100 & 100 & 100 & 100 & 100 \\
$8^{\prime \prime}$ & 80 & 74 & 92 & 74 & 70 & 112 & 112 \\
$9 \prime \prime$ & 68 & $8 \mathrm{r}$ & 82 & 68 & 65 & 95 & 156 \\
$10 \prime \prime$ & 87 & 92 & 129 & 87 & 78 & 110 & $1 \times 9$ \\
\hline
\end{tabular}




\section{v. Conclusions.}

Attempts have been already made to describe my observations and results. These findings will be summarized as follows :

I. The most ocular muscles consist of two kinds of muscle fibres, namely axial thick and peripheral fine fibres.

2. The size of muscle fibres in the ocular muscles is subject to fluctuation not only with different muscles, but also with different individuals and body-sides to which the muscles belong. The greatest size of muscle fibres is in axial part 507.2 sq. $\mu$ and in peripheral part I99.2 sq. $\mu$, while the smallest is in the former 97.8 sq. $\mu$ and in the latter 34.7 sq. $\mu$.

3. The proportion between the size of axial thick fibres and peripheral fine fibres in an ocular muscle is on the average in all kinds of ocular muscles almost the same and the axial fibres are in general in all kinds of muscles about 3 times thicker than the peripheral fibres.

4. There is seen a variation of the size of muscle fibres between the ocular muscles on one body-side. The proportion between the highest and the lowest size on one body-side varies in axial part from 1.08 to 2.45 , corresponding to the average value of $r .67$. It lies in peripheral part between r.07 and 2.12, presenting the average value of 1.41 . These facts indicate that the variation of the size of peripheral fine fibres among 7 ocular muscles on one body-side is very small and smaller than that of the size of axial thick fibres.

5. Between the same named muscles on both sides, there is a somewhat high correlation with regard to the size of muscle fibres. The correlation coefficient is in axial part $0.79 \pm 0.045$ and in peripheral part $0.58 \pm 0.079$.

6. The order of the size of muscle fibres in axial as well as in peripheral part of the ocular muscles varies according to each body-side and each fetus. There is no fetus which shows the same order on both sides.

7. The size of axial thick fibres is in general the largest in Rectus lateralis, followed in order by Rectus superior, Rectus medialis, Obliquus inferior, Rectus inferior and Obliquus superior, being the smallest in Levator palpebrae superioris, although the order is not always the same on each bodyside. The order of the size of peripheral fine fibres is not the same with that of axial thick fibres and ranges as follows: Rectus superior, Rectus lateralis, Obliquus superior, Levator palpebrae superioris, Rectus inferior, Obliquus inferior and Rectus medialis.

8. The right percentage, i.e., the percentage of the size of muscle fibres in a right muscle to the sum of the size of fibres in the two "corresponding muscles on both sides, is in axial part in 42 and in peripheral part in 21 out 
of 70 muscle pairs higher than $50.00 \%$. The average value of the right and left percentage is in axial part $51.30 \pm 0.96 \%$ and $48.70 \pm 0.96 \%$, and in peripheral part $48.15 \pm 0.75 \%$ and $51.85 \pm 0.75 \%$. In the axial part, there is no significant difference between the right and left percentage, while in the peripheral part a significant difference is found. From this it may be said, that with regard to the size of axial thick fibres the right and left muscles show no significant difference between them, whereas the size of peripheral fine fibres is generally in the left muscles greater than in the right muscles.

9. The difference between the right and left percentage, i.e., the percentage of the difference of the size of muscle fibres between the right and left same named muscles against the sum of the size of fibres in the two muscles, varies in axial part from $1.22 \%$ to $41.20 \%$, and lies in peripheral part between $0.04 \%$ and $34.36 \%$. The difference is in axial part in 27 and in peripheral part in 37 out of 70 muscle pairs lower than $10.00 \%$.

Io. The average value of this difference in the 70 examined muscle pairs is in axial part $13.83 \pm 1.07 \%$ and in peripheral part $10.59 \pm 0.92 \%$. It is therefore right to declare that with regard to the size of muscle fibres the difference between the same named muscles on both sides comes in average to $13.83 \pm 1.07 \%$ (axial thick fibres) and $10.59 \pm 0.92 \%$ (peripheral fine fibres) for the sum of the size of muscle fibres in the two corresponding muscles. As these figures indicate, the size of peripheral fine fibres in the same named muscles on both sides is more closely related with each other than that of the axial thick fibres.

Ir. In the examined fetuses, the size of axial thick fibres as well as of peripheral fine fibres is in the majority of cases in the female fetuses larger than in the male fetuses of the same age.

x2. The size of muscle fibres shows in the examined fetal stages a tendency to increase with increasing age and the increase is in axial thick fibres of higher degree than in peripheral fine fibres.

13. The extent of the increase of the size of ocular muscles is a little smaller than that of the number of muscle fibres in them.

I wish to acknowledge my indebtedness to Prof. Dr. S. Mochizuki for his kind incitement. I am also grateful to Assistent-Prof. Dr. S. Ka to for his kind guidance to this investigation.

The literature cited therein will appear in the last report of this investigation. 